E-ISSN : 2580-7056, ISSN : 2580-7064

Pascasarjana IAIN Palangka Raya

\title{
MOTIVASI IBU-IBU MENGIKUTI PENGAJIAN DI BADAN KONTAK MAJELIAS TAKLIM (BKMT) KOTA PALANGKA RAYA
}

\author{
Hamdanah \\ Dosen IAIN Palangka Raya \\ Jl. Jintan, G. Obos IX, Kota Palangka Raya
}

\begin{abstract}
ABSTRAK
The Board Contact of Majelis Taklim (BCMT) is an educational medium that seeks to instill a noble character, increase taqwa, knowledge and skills as an effort to educate the life of the nation and promote the welfare of the ummah in order to seek the pleasure of Allah SWT. Many Islamic gatherings were held by Muslim ladies on a regular basis such as weekly and even up to 3 times a week as well as monthly.

Research questions are (1) What is the motivation that makes the ladies very enthusiastic about taking part in Islamic gatherings? In addition, what are the factors making the Muslim ladies enthusiastic about attending the study at Board Contact Majelis Taklim of Palangka Raya Municipality? (2) What are the implications of Muslim ladies' participation in the Islamic gatherings at Board Contact Majelis Taklim of Palangka Raya Municipality?

The approach used is qualitative with a phenomenological study, by using a technique of Purposive Sampling and the subjects in this research are Muslim ladies taking part in Islamic gatherings from Aisyiyah, Nahdatul Ulama Season, Nasyiyatul Asyiyah, Fatayat Nahdatul Ulama and Mar 'atus sholehah with a total number of 15 people, with data collection techniques of observation, interviews and documentation.

Results of the research suggest that the Muslim ladies were motivated about taking part in the Islamic gatherings because they wanted to study and deepen their religious knowledge, thought that their participation was worship, made their souls peaceful, communicated with other members of the Islamic gatherings, and united them. Furthermore, some factors affecting them to take part in the gatherings were internal and external ones. Additionally, implications of the Islamic gatherings were that the ladies were motivated to communicate with other members, be more patient when having some family problems, do Tahajjud and Dhuha prayers, frequently spell some zikirs, be forgiving to their friends and families, have peaceful and calm feeling.

It is expected that after the Islamic gatherings for Muslim ladies, the subjects could apply their gained knowledge, to both themselves and others.
\end{abstract}

Keywords: ladies motivation, Islamic gathering for ladies, Board Contact of Majelis

\section{Taklim (BCMT)}


E-ISSN : 2580-7056, ISSN : 2580-7064

Pascasarjana IAIN Palangka Raya

\section{A. Latar Belakang Masalah}

Pendidikan pada dasarnya merupakan tanggung jawab bersama antara pemerintah, masyarakat dan keluarga. Atas dasar tanggung jawab ini pendidikan di Indonesia diselenggarakan melalui tiga jalur, yaitu pendidikan formal, non formal dan informal. ${ }^{1}$

Agama Islam menekankan kepada umatnya untuk melaksanakan pendidikan baik pendidikan umum maupun pendidikan agama. Peranan agama sangat penting dalam kehidupan manusia, sebab agama merupakan sangat diperlukan dalam kehidupan masyarakat. Melalui pendidikan agama diharapkan nilai-nilai agama dapat diterapkan oleh peserta didik. Hal ini juga mendukung dalam usaha mencapai tujuan Pendidikan Nasional sebagaimana tercantum dalam Undang-Undang No. 20 Tahun 2003 pada Bab II pasal 3 yang berbunyi: Pendidikan nasional berfungsi mengembangkan kemampuan dan membentuk watak serta peradaban bangsa yang bermartabat dalam rangka mencerdaskan kehidupan bengsa, bertujuan untuk berkembangnya potensi peserta didik agar menjadi manusia yang beriman dan bertakwa kepada Tuhan Yang Maha Esa, berakhlak mulia, sehat, berilmu, cakap, kreatif, mandiri dan menjadi warga Negara yang berdemokrasi serta bertanggung jawab. ${ }^{2}$

Dengan pendidikan manusia berusaha mengembangkan aspek-aspek kepribadiannya baik jasmaniah maupun rohaniah, termasuk didalamnya aspek individualitas, moralitas dan aspek religius, serta aspek sosialitas sehingga dengan pendidikan itu akan tercapai kehidupan yang harmonis, seimbang antara kebutuhan fisik material dan kebutuhan mental spritual dan antara dunia dan ukhrawi. Jadi, pendidikan tidak hanya didapatkan di sekolah (formal) tetapi ada juga pendidikan di luar sekolah (non-formal), salah satunya yaitu pengajian agama di majelis taklim, les, privat, dan lain-lain.

Umat Islam disuruh belajar dan mengajarkan ilmunya kepada orang lain, dan bahkan orang yang tidak berilmu wajib menuntut ilmu atau belajar untuk dapat beramal baik, sementara orang yang berilmu wajib menyampaikan dan berbagi pengetahuan yang dimiliknya kepada orang lain dengan cara yang baik. Seperti yang terdapat dalam surah At Taubah ayat 122 sebagai berikut :

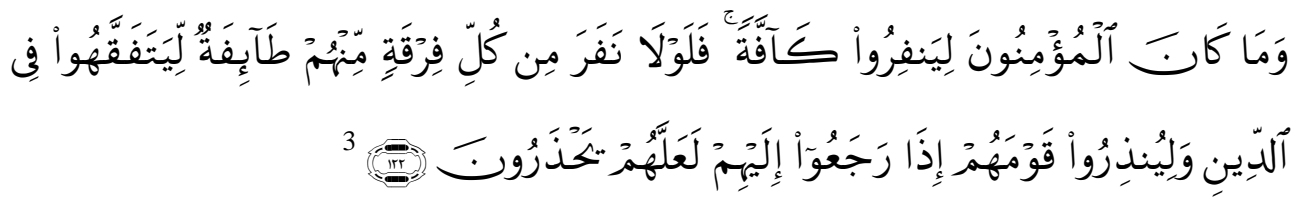

Artinya :

"Tidak sepatutnya bagi mukminin itu pergi semuanya (ke medan perang). mengapa tidak pergi dari tiap-tiap golongan di antara mereka beberapa orang untuk memperdalam pengetahuan mereka tentang agama dan untuk

\footnotetext{
${ }^{1}$ Barsihannor, Belajar dari Luqman al-Hakim (Yogyakarta : Kota Kembang, 2011), h. 1.

${ }^{2}$ UU RI Nomor 20 Tahun 2003, Bab IV pasal 27 ayat 1 (Bandung : Citra Umbara, 2003), h.13

${ }^{3}$ Departemen Agama, Al Q ur'an dan Terjemahnya, cet.( Jakarta : 2002). h. 644.
} 
E-ISSN : 2580-7056, ISSN : 2580-7064

Pascasarjana IAIN Palangka Raya

memberi peringatan kepada kaumnya apabila mereka telah kembali kepadanya, supaya mereka itu dapat menjaga dirinya."

Pengajian agama adalah salah satu sarana untuk memperdalam ilmu agama, dan mempunyai tujuan untuk memberikan arah dan membimbing masyarakat mendapatkan keselamatan dunia dan akhirat, mampu mencapai tujuan hidup yang hakiki yaitu terbentuknya insan yang senantiasa berhamba kepada Allah Swt dalam semua aspek hidupnya.

Dalam masyarakat Islam, pengajian agama atau majlis Taklim merupakan sistem pendidikan non-formal yang selalu berkembang dari sejak adanya agama Islam sampai sekarang. Pengajian agama yang dilakukan oleh masyarakat muslim dapat memberikan berbagai pengetahuan agama sebagai way of life bagi umat Islam. Pengajian agama merupakan kegiatan pendidikan non formal yang banyak dilakukan di masyarakat, dan diselenggarakan sebagai usaha dakwah di kalangan masyarakat muslim.

Pengajian merupakan salah satu institusi dan kegiatan dalam masyarakat Islam yang memiliki multi-fungsi. Di samping sebagai salah satu bentuk pendekatan dan sekaligus instrumen dakwah, pengajian juga berfungsi dan berperan sebagai lembaga pendidikan non-formal di tengah masyarakat. Bahkan pengajian dapat berfungsi dan berperan sebagai wahana bimbingan dan penyuluhan (konseling) kelompok kepada warga masyarakat Islam yang membutuhkannya. Sebagai bentuk pendekatan dan instrumen dakwah, pengajian akan selalu ada dalam masyarakat Islam, sejalan dengan keharusan atas keberadaan kegiatan dan gerakan dakwah. Menurut M. Quraish Shihab, dakwah merupakan satu bagian yang pasti ada dalam kehidupan umat beragama. Dalam ajaran Islam, dakwah merupakan suatu kewajiban yang dibebankan oleh agama kepada pemeluknya. Oleh karena itu, kegiatan dakwah bukan semata-mata timbul dari pribadi atau golongan, melainkan muncul dari doktrin Islam itu sendiri, walaupun tentu saja harus ada segolongan (tha'ifah) umat Islam yang melaksanakannya. ${ }^{4}$

Menurut Ali Abdul Halim Mahmud, pengajian memiliki peranan penting dalam menegakkan amar ma'ruf Nahi Mungkar di masyarakat, yaitu sebagai pilarpilar utama Tarbiyah Islamiyah ${ }^{5}$. Kegiatan pengajian yang dapat dijadikan sebagai wadah pembentukan jiwa dan kepribadian yang agamis sekaligus berfungsi sebagai stabilisator dalam seluruh gerak aktifitas kehidupan manusia, sudah selayaknyalah kegiatan-kegiatan yang bernuansa Islam mendapat perhatian dan dukungan dari masyarakat, sehingga tercipta insan-insan yang memiliki keseimbangan potensi dari segi intelektual maupun mental spiritual sekaligus memiliki kepribadian yang Islami dalam mengadapi perubahan zaman yang semakin global.

Kehadiran majelis pengajian sangat diharapkan dapat memberikan konstribusi positif terhadap pembinaan agama anggota sekitarnya, mulai dari

${ }^{4}$ M. Quraish Shihab, Membumikan Al-Quran: Fungsi dan Peran Wahyu dalam Kehidupan Masyarakat (Bandung: Mizan, 1992), h. 194.

${ }^{5}$ Ali Abdul Halim Mahmud, Pendidikan Ruhani, Terjm. Abdul Hayyie al - Kattani (Jakarta : Gema Insani Press, 2000), h. 51 
E-ISSN : 2580-7056, ISSN : 2580-7064

Pascasarjana IAIN Palangka Raya

memfungsikan masjid, dan mushalla, aula maupun dengan memanfaatkan rumah para jamaa'ah.

Kegiatan pengajian mengarahkan kepada kegiatan kelompok social, karena dalam pengajian terjadi interaksi antara individu, ada yang memimpin dan ada yang dipimpin dengan berbagai metode tertentu. Dalam teori kelompok sosial situasi yang seperti ini termasuk situasi kebersamaan. Menurut Slamet Santosa berpendapat, bahwa kelompok sosial dengan situasi kebersamaan dapat dijabarkan suatu kelompok individu yang berkumpul pada suatu ruang dan waktu yang sama, tumbuh dan mengarahkan tingkah laku yang spontan. ${ }^{6}$

Pengajian sebagai dakwah Islam, yang menarik banyak peminat dalam hal mustammi, mulai dari kaum bapak-bapak, ibu-ibu, dan tak ketinggalan juga kaum remaja. Dari pengajian yang ada, maka yang lebih dominan dalam melaksanakan pegajian adalah kaum ibu di bandingkan dengan kaum Bapak secara kuantitas.

Pengajian yang dilaksakan oleh kaum ibu-ibu terhimpun dalam suatu wadah yang disebut dengan Badan Kontak Majelis Taklim atau yang dikenal dengan BKMT dengan beranggotakan ibu-ibu. Majelis taklim merupakan salah satu lembaga pendidikan keagamaan khas Islam yang tumbuh subur di tengahtengah masyarakat. Lembaga ini hampir terdapat di setiap komunitas muslim yang keberadaannya telah banyak berperan dalam pengembangan dakwah Islam. BKMT ini sebagai induk atau umbrella dari ratusan bahkan ribuan pengajian yang tersebar di pelosok tanah air, diakui telah menyumbangkan peran yang amat besar dalam mencerdaskan ummat dan bangsa khususnya dalam mengajarkan agama, melalui majelis taklim ini masyarakat yang terlibat didalamnya dapat merasakan betapa keberadaan lembaga ini menjadi sarana pembinaan moral spiritual serta menambah pengetahuan keislaman guna meningkatkan kualitas sumber daya muslim yang beriman dan bertakwa kepada Allah SWT.

Badan Kontak Majelis Taklim merupakan bagian dari lingkungan social memiliki kedudukan strategis, berperan sebagai wahana pendidikan yang berusaha menanamkan akhlak yang mulia, meningkatkan ketaqwaan, pengetahuan dan kecakapan yang diabdikan sebagai upaya untuk mencerdaskan kehidupan bangsa dan memajukan kesejahteraan ummat dalam rangka mencari keridhaan Allah SWT. ${ }^{7}$

Berdasarkan fenomena yang ada di Kota Palangka Raya, umumnya pengajian yang dilaksanakan ibu-ibu bermacam-macam, sangat beragam, ada yang namanya pengajian Al Qur'an, yasinan, burdahan, dalail, habsyi, ad diba'i dan lain-lain, semuanya diikuti oleh mayoritas kaum ibu, sehingga hampir di setiap RT/RW. Pelaksanaan pengajian tersebut setiap minggu satu pengajian. Kaum ibu terkadang sampai 3 (tiga) kali dalam seminggu bahkan ada lagi pengajian rutin yang dilaksanakan dalam setiap bulan, disebut dengan pengajian bulanan yang juga diikuti oleh kaum ibu-ibu. Apalagi kalau acara hari-hari besar

\footnotetext{
${ }^{6}$ Slamet Santosa, Dinamika Kelompok (Jakarta : Bumi Aksara, 2006), h. 33

${ }^{7}$ Pengurus Pusat BKMT, Anggaran dasar dan Anggaran rumah Tangga, (Jakarta : PP. BKMT, 2011), hal. 1 
E-ISSN : 2580-7056, ISSN : 2580-7064

Pascasarjana IAIN Palangka Raya

Islam, seperti Maulid dan Isra' Mi'raj, mereka berbondong-bondong untuk mengikuti kegiatan tersebut dan terkadang pelaksanaannya setiap hari dengan berpindah-pindah tempat. Berdasarkan hal tersebut penulis tertarik untuk meneliti motivasi apa yang membuat kaum ibu-ibu sangat antusias dalam mengikuti pengajian? Apakah dikarenakan mereka haus dengan ilmu pengetahuan agama, sehingga mereka tergerak untuk menghadiri pengajian secara rutin? Apakah juga karena mereka termotivasi mengikuti pengajian tersebut karena merasa ada kewajiban menuntut ilmu agama, sebagai bekal dalam hidup di dunia dan di akhirat kelak, atau juga ingin mencari ketenangan batin, atau ingin bersilaturrahmi, atau juga karena diadakan arisan supaya bisa ngumpul-ngumpul dengan ibu-ibu yang lain. Faktor-faktor apakah yang menyebabkan ibu-ibu sangat antusias mengikuti pengajian tersebut? Apakah dipengaruhi oleh Faktor intern? misalnya latar belakang pendidikan ibu-ibu, pekerjaan ibu-ibu, minat ibu-ibu. Ataukah juga dipengaruhi oleh faktor ekstern seperti; Ajakan dari orang lain, pelaksanaan kegiatan pengajian dan kualitas pengajian, Guru/da'i dalam memberikan pengajian dengan kemampuan profesionalnya, lingkungan tempat tinggal atau masyarakat sekitar lokasi pengajian. Bagaimana implikasi ibu-ibu setelah mengikuti pengajian tersebut?

Berdasakan dari fenomena di atas penulis tertarik untuk membuat sebuah penelitian dengan judul "Motivasi ibu-ibu mengikuti Pengajian di Badan Kontak Majelis Taklim Kota Palangka Raya".

\section{B. Metode Penelitian}

\section{Pendekatan Penelitian}

Sesuai dengan permasalahan yang dikaji, maka penelitian ini menggunakan pendekatan kualitatif dengan kajian fenomenologis. Pemilihan pendekatan ini dilakukan dengan dasar bahwa data yang dibutuhkan lebih terfokus pada motivasi ibu-ibu mengikuti pengajian di BKMT Kota Palangka Raya. Data dihimpun dalam keadaan sewajarnya, menggunakan cara yang sistematis, terarah dan dapat dipertanggung jawabkan, sehingga tidak kehilangan sifat keilmiahannya. Penelitian kualitatif mengejar kebenaran lewat temuannya dari sumber terpercaya, sehingga hal yang hakiki, yang esensial dapat ditemukan, kebenaran tidak diukur berdasarkan frekuensi dan variasi.

\section{Subjek Penelitian}

Subjek penelitian ini adalah ibu-ibu yang mengikuti pengajian di BKMT kota Palangka Raya, menggunakan teknik purposive sampling, dengan kriteria sebagai berikut :

a) Ibu-ibu yang berasal dari pengurus/anggota organisasi Aisyiyah (baik kota maupun wilayah) berjumlah 3 orang

b) Ibu-ibu dari pengurus/anggota Muslimat Nahdatul Ulama sebanyak 3 orang

c) Ibu-ibu dari pengurus/anggota Fatayat Nahdatul Ulama sebanyak 3 orang

d) Ibu-ibu dari pengurus/anggota Nasyiatul Aisyiyah sebanyak 3 orang 
E-ISSN : 2580-7056, ISSN : 2580-7064

Pascasarjana IAIN Palangka Raya

e) Ibu-ibu dari pengurus/anggota pengajian Mar'atus Sholehah sebanyak 3 orang

Dari kriteria di atas, maka penulis mengambil 15 orang ibu-ibu yang mengikuti pengajian di BKMT Kota Palangka Raya.

\section{Tehnik Pengupulan Data}

Pengumpulan data dilakukan melalui observasi, wawancara mendalam dan dokumentasi. Untuk menjamin keabsahan data perlu dilakukan triangulasi. Tehnik triangulasi yang digunakan lebih banyak pada triangulasi sumber, metode dan teori. Sedangkan teknik analisis data dibagi dalam tiga alur kegiatan yang terjadi secara bersamaan, yaitu reduksi data, penyajian data dan penarikan kesimpulan atau verifikasi.

\section{Kerangka Pikir/Koseptual}

Mencermati judul dan rumusan masalah yang penulis buat tentang Motivasi Ibu-ibu mengikuti Pengajian di Badan Kontak Majelis Taklim Kota Palangka Raya, maka tidak terlepas dari pengertian motivasi sebagai salah satu faktor psikologis yang merupakan pendorong dari individu atau jamaah pengajian untuk melakukan berbagai aktivitas mengikuti pengajian agama. Motivasi yang kuat dan jelas mampu mengantarkan seseorang pada tujuan akhir dari aktivitasnya. Sebaliknya motivasi yang kurang jelas bahkan tidak ada sama sekali atau tidak mampu membawa peserta pengajian kepada tujuan yang diharapkan. Tujuan akhir dari motivasi tersebut adalah adanya impikasi ibu-ibu setelah mengikuti pengajian.

Untuk lebih jelasnya dapat di lhat skema/Tabel berikut : 
E-ISSN : 2580-7056, ISSN : 2580-7064

Pascasarjana IAIN Palangka Raya

Tabel 1

Kerangka Pikir

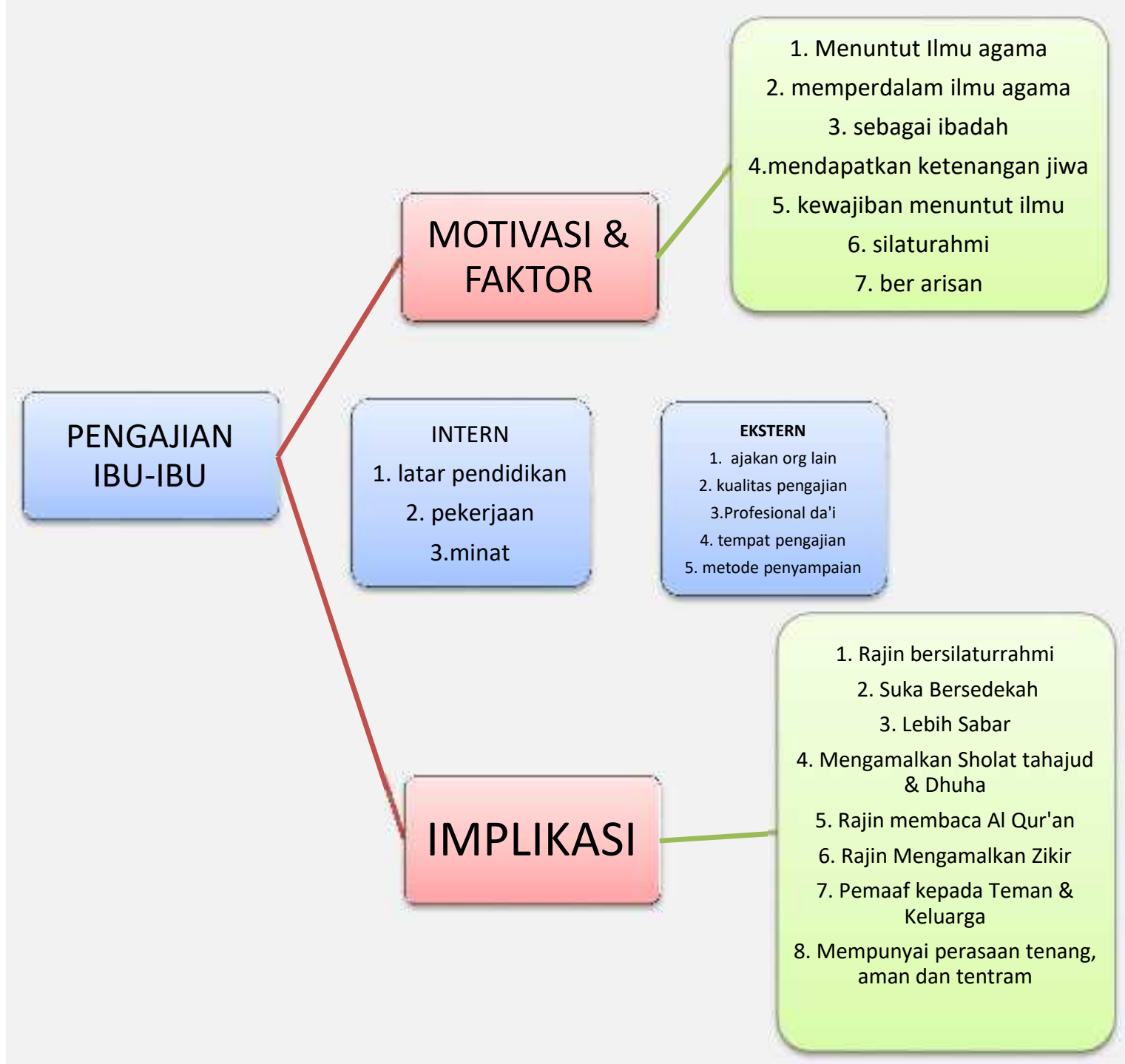


E-ISSN : 2580-7056, ISSN : 2580-7064

Pascasarjana IAIN Palangka Raya

\section{E. Kerangka Teori}

Kata motif (motive), berasal dari akar kata bahasa latin movere, yang kemudian menjadi motif; artinya gerak atau dorongan untuk bergerak. Jadi motif merupakan daya dorong, daya gerak, atau penyebab seseorang melakukan berbagai perbuatan dengan tujuan tertentu. ${ }^{8}$ Menurut Al Kinso dan kawan-kawan seperti yang dikutip Abd. Racman Abror, "Motivasi mengacu kepada faktor-faktor yang menggerakan dan mengarahkan tingkah". ${ }^{9}$ Lebih lanjut Wlodkowski menjelaskan motivasi sebagai suatu kondisi yang menyebabkan atau menimbulkan perilaku tertentu, dan yang memberi arah serta ketahanan (persistence) pada tingkah laku tersebut. Pengertian ini jelas bernafaskan behaviorisme. Sedangkan Imron menjelaskan, bahwa motivasi berasal dari bahasa Inggris motivation, yang berarti dorongan pengalasan dan motivasi. Kata kerjanya adalah to motivate yang berarti mendorong, menyebabkan dan merangsang. Motive sendiri berarti alasan, sebab dan daya penggerak. Motif adalah keadaan dalam diri seseorang yang mendorong individu tersebut untuk melakukan aktivitas-aktivitas tertentu guna mencapai tujuan yang diinginkan". ${ }^{10}$ Wlodkowski menjelaskan motivasi sebagai suatu kondisi yang menyebabkan atau menimbulkan perilaku tertentu, dan yang memberi arah serta ketahanan (persistence) pada tingkah laku tersebut. Pengertian ini jelas bernafaskan behaviorisme. Sedangkan Imron menjelaskan, bahwa motivasi berasal dari bahasa Inggris motivation, yang berarti dorongan pengalasan dan motivasi. Kata kerjanya adalah to motivate yang berarti mendorong, menyebabkan dan merangsang. Motive sendiri berarti alasan, sebab dan daya penggerak. Motif adalah keadaan dalam diri seseorang yang mendorong individu tersebut untuk melakukan aktivitas-aktivitas tertentu guna mencapai tujuan yang diinginkan". ${ }^{11}$

Menurut Mc Donald, motivasi adalah perubahan energi dalam diri seseorang yang ditandai dengan munculnya "feeling" dan didahului dengan tanggapan terhadap adanya tujuan.

Teori kebutuhan, setiap manusia bertindak senantiasa didorong untuk memenuhi kebutuhan-kebutuhan tertentu.Teori ini dikemukakan oleh Abraham Maslow. ${ }^{12}$. Ada lima dasar kebutuhan dasar manusia, kelima kebutuhan dasar tersebut ialah sebagai berikut:

1) Kebutuhan fisiologis (Physiological Needs)

2) Kebutuhan akan rasa aman (Safety/Security Needs)

3) Kebutuhan akan cinta dan kasih (Social Needs)

4)Kebutuhan akan penghargaan ((Esteem Needs)

5)Kebutuhan akan aktualisasi diri”. ((Self-actualization Needs $)^{13}$

Dalam Al Qur'an, Allah SWT berfirman :

\footnotetext{
${ }^{8}$ Abd. Rachman Abror, Psikologi Pendidikan (Yogyakarta : Tiara Wacana, 1999), h 144

${ }^{9}$ Ibid, hlm 145

${ }^{10}$ Evelin Siregar, Teori Belajar dan Pembelaaran, (Bogor: Ghalia Indonesia, 2010) , h. 49

${ }^{12}$ Evelin Siregar, Teori Belajar dan Pembelaaran, Bogor: Ghalia Indonesia, 2010, h.50

${ }^{13}$ Slameto, Belajar dan Faktor-faktor yang Mempengaruhinya, Jakarta:Rineka Cipta, 2010, h. 171
} 
E-ISSN : 2580-7056, ISSN : 2580-7064

Pascasarjana IAIN Palangka Raya

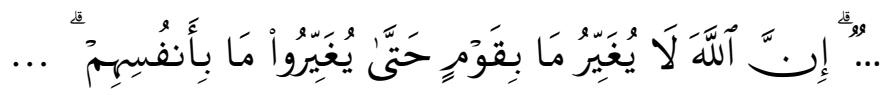

Artinya :

“... Sesungguhnya Allah tidak mengubah keadaan suatu kaum sehingga mereka mengubah keadaan yang ada pada diri mereka sendiri...." (ArRa'd: 11)

Dari ayat di atas menggambarkan bahwa ternyata motivasi yang paling kuat adalah dari diri seseorang. Motivasi sangat berpengaruh dalam gerak-gerik seseorang dalam setiap tindak-tanduknya. Apabila dikaitkan dengan tingkah laku keagamaan, maka motivasi tersebut penting untuk dibicarakan sebab akan dapat mengetahui apa sebenarnya yang melatar belakangi suatu tingkah laku keagaman yang dikerjakan seseorang. Disini peranan motivasi itu sangat besar artinya dalam bimbingan dan mengarahkan seseorang terhadap tingkah laku keagamaan. Namun demikian ada motivasi tertentu yang sebenarnya timbul dalam diri manusia karena terbukanya hati manusia terhadap hidayah Allah. Sehingga orang tersebut menjadi orang yang beriman dan kemudian dengan iman itulah ia lahirkan tingkah laku keagaman.

Menurut Ramayulis, peran motivasi dalam kehidupan manusia sangat banyak, diantaranya :

a. Motivasi sebagai pendorong manusia dalam melakukan sesuatu, sehingga menjadi unsur penting dan tingkah laku atau tindakan manusia

b. Motivasi bertujuan untuk menentukan arah dan tujuan

c. Motivasi berfungsi sebagai penguji sikap manusia dalam beramal benar atau salah sehingga bisa dilihat kebenarannya dan kesalahannya

d. Motivasi berfungsi sebagai penyeleksi atas perbuatan yang akan dilakukan oleh manusia baik atau buruk. Jadi motivasi itu berfungsi sebagai pendorong, penentu, penyeleksi dan penguji sikap manusia dalam kehidupanya. ${ }^{14}$

Dalam al Qur'an ditemukan beberapa statement baik secara eksplisit maupun implisit yang menunjukkan beberapa bentukan dorongan yang mempengaruhi manusia. Seperti yang terdapat dalam Surah Ar-rum ayat 30, Allah menjelaskan bahwa potensi yang dimiliki seseorang (manusia) adalah fitrah sebuah potensi dasar. Potensi dasar yang memiliki makna sifat bawaan, yang dibawa sejak lahir mengandung arti bahwa sejak diciptakan manusia memiliki sifat bawaan yang menjadi pendorong untuk melakukan berbagai macam bentuk perbuatan, tanpa disertai dengan peran akal, sehingga terkadang

${ }^{14}$ Ramayulis, Psikologi Agama,(Jakarta : Kalam Mulia, 2011), h. 102

JURNAL TRANSFORMATIF (Islamic Studies)

Volume 1, Nomor 2, Oktober2017 
E-ISSN : 2580-7056, ISSN : 2580-7064

Pascasarjana IAIN Palangka Raya

manusia tanpa disadari bersikap dan bertingkah laku untuk menuju pamenuhan fitrahnya. Manusia selain sebagai makhluk rasionalistik juga sebagai makhluk metafisik, yaitu makhluk yang digerakkan oleh sesuatu di luar nalar yang biasanya disebut naluri atau insting.

Setiap perbuatan yang dilakukan manusia baik yang disadari atau (rasional) maupun yang tidak disadari (mekanikal atau naluri) pada dasarnya merupakan sebuah wujud untuk menjaga sebua keseimbangan hidup. Jika keseimbangan tubuh ini terganggu, maka akan timbul suatu dorongan untuk melakukan aktivitas guna mengembalikan keseimbangan tubuh.

Al-Qur'an menyebutkan ada beberapa motivasi aktivitas hidup seseorang, yakni :

1) Tidak ada motivasi atau tendensi apapun dalam ibadah, hidup dan mati ini kecuali semata-mata karena Allah. Firman Allah SWT:

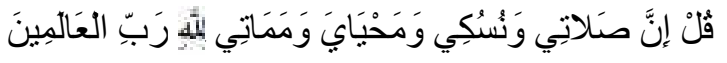

Artinya:

"Katakanlah: sesungguhnya sembahyangku, ibadatku, hidupku dan matiku hanyalah untuk Allah, Tuhan semesta alam." (QS AlAn'am:162)

2) Semata-mata ikhlas karena Allah SWT, sebab hal itu merupakan bentuk beragama yang benar. Firman Allah SWT:

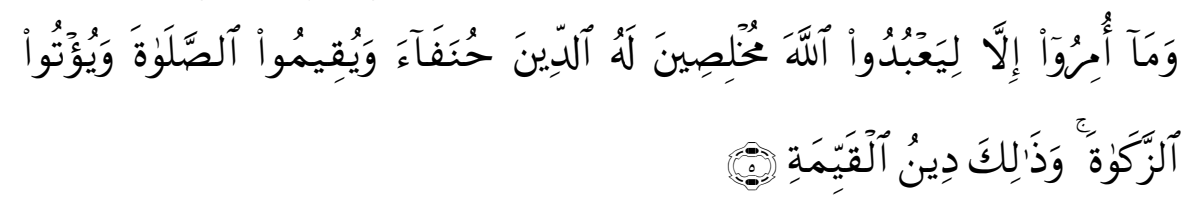

Artinya :

"Padahal mereka tidak disuruh kecuali supaya menyembah Allah dengan memurnikan ketaatan kepada-Nya dalam (menjalankan) agama yang lurus, dan supaya mereka mendirikan shalat dan menunaikan zakat; dan yang demikian Itulah agama yang lurus."'(QS Al-Bayyinah: 5)

3) Untuk mencapai kebaikan dan kebahagiaan hidup di dunia dan di akhirat dan terhindar dari siksaan api neraka. Firman Allah:

Artinya:

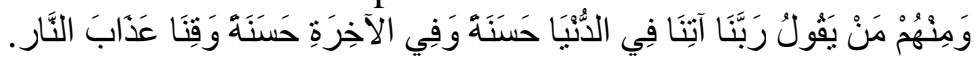

"Dan diantara mereka ada orang yang bendo'a: "Ya Tuhan kami, berilah kami kebaikan di dunia dan kebaikan di akhirat dan peliharalah kami dari siksa neraka".(QS. Annisa : 4).

Ada 2 (dua) faktor yang mempengaruhi motivasi tersebut, yakni Internal dan Eksternal. Dari 2 faktor tersebut timbullah implikasi ibu-ibu setelah mengikuti pengajian tersebut. Motivasi merupakan pendorong bagi tindakan seseorang dalam merah cita-cita. Di mana semakin tinggi cita-cia yang akan 
E-ISSN : 2580-7056, ISSN : 2580-7064

Pascasarjana IAIN Palangka Raya

diraih oleh seseorang maka sebagai konsekkuensinya semakin kuat pula motif yang mendasarinya, sehingga tidak mengherankan jika ada seseorang yang dapat meraih atau mencapai jenjang prestasi tertentu dan posisi tertentu, sedang oranglain tidak dapat mencapainya. Banyak faktor yang mempengaruhi motivasi manusia, diantaranya adalah dorongan yang secara spontan dan alamiah yang terjadi pada manusia. kelakuan manusia atau lingkungannya. ${ }^{15}$

Majelis taklim mengandung beberapa pengertian yang berbeda-beda. Effendy Zarkasyi dalam buku Manajemen Majelis Taklim yang dikarang oleh Muhsin menyatakan, bahwa majelis taklim bagian dari model dakwah dewasa ini dan sebagai forum belajar untuk mencapai suatu tingkat pengetahuan agama. ${ }^{16}$ Syamsuddi Abbas juga mengemukakan pendapatnya, dimana ia mengartikan sebagai "lembaga pendidikan non-formal Islam yang memiliki kurikulum sendiri, diselenggarakan secara berkala dan teratur, dan diikuti oleh jamaah yang relatif banyak". ${ }^{17}$

Sedangkan menurut Musyawarah Majelis Taklim se-DKI pada tanggal 9-10 Juli 1980 merumuskan defenisi (ta'rif) mejelis taklim, yaitu lembaga pendidikan Islam non-formal yang memiliki kurikulum tersendiri, diselenggarakan secara berkala dan teratur, dan diikuti oleh jamaah yang relatif banyak, dan bertujuan untuk membina dan mengembangkan hubungan yang santun dan serasi antara manusia dan Allah Swt (habluminallah), dan antara manusia dan sesama (habluminannas) dan dengan lingkungan dalam rangka membina pribadi dan masyarakat bertakwa kepada Allah Swt. ${ }^{18}$

\section{F. Gambaran Umum Penelitian}

\section{Gambaran singkat Kota Palangka Raya}

Sejarah pembentukan kota Palangka Raya ${ }^{19}$ yang merupakan bagian integral dari pembentukan Propinsi Kalimantan Tengah merupakan implementasi dari Undang-undang Darurat Nomor 10 tahun 1957, Lembaran Negara Nomor 53 berikut penjelasannya (Tambahan Lembaran Negara Nomor 1284) berlaku mulai tanggal 23 Mei 1957, yang selanjutnya disebut Undangundang Pembentukan Daerah Swatantra Propinsi Kalimantan Tengah.

Menurut Undang-Undang Nomor 21 Tahun 1958, Parlemen Republik Indonesia tanggal 11 Mei 1959 mengesahkan Undang-Undang Nomor 27 Tahun 1959 yang isinya menetapkan pembagian Propinsi Kalimantan Tengah dalam 5 (lima) Kabupaten dan Palangka Raya sebagai ibukotanya.

Berdasarkan Surat Keputusan Menteri Dalam Negeri RI Nomor Des. 52/12/2-206 tanggal 22 Desember 1959 ditetapkanlah pemindahan tempat

\footnotetext{
${ }^{15}$ Niko Syukur Dister, Pengalaman dan Motivasi Beragama (Yogyakarta : Kanisius, 1994), h. 74

${ }^{16}$ Muhsin, MK, Manajemen Majelis Taklim : Petunjuk Praktis Pengelolaan Dan Pembentukannya (Jakarta : Inter Massa, 2009) Cet. Ke-1, h. 1

${ }^{17}$ Syamsuddin Abbas, Memperkuat Kelembagaan Masjid, Madrasah, dan Koperasi. Jakarta: Yayasan Amal Shaleh Akkajeng [YASKA], 2000. h. 72.

${ }^{18}$ M Natsir Zubaidi, ed., Mendesain Masjid Masa Depan. Jakarta: Pustaka Insani Indonesia, 2006. h. 29.

${ }^{19}$ BPS, Palangka Raya City in Fugures Tahun 2009, hlm 39
}

JURNAL TRANSFORMATIF (Islamic Studies) 
E-ISSN : 2580-7056, ISSN : 2580-7064

Pascasarjana IAIN Palangka Raya

kedudukan Pemerintah Daerah Kalimantan Tengah dari Banjarmasin ke Palangkaraya terhitung mulai tanggal 20 Desember 1959. Selanjutnya Kecamatan Kahayan Tengah yang berkedudukan di Pahandut secara bertahap mengalami perubahan dengan mendapat tambahan tugas dan fungsinya, antara lain mempersiapkan Kotapraja Palangkaraya. Kemudian pada tahun yang sama Kecamatan Kahayan Tengah di Pahandut dipindahkan ke Bukit Rawi. Pada tanggal 11 Mei 1960 dibentuk pula Kecamatan Palangka Khusus persiapan Kotapraja Palangkaraya. Perubahan, peningkatan dan pembentukan yang dilaksanakan untuk kelengkapan Kotapraja Administratif Palangkaraya dengan membentuk 3 (tiga) Kecamatan yaitu:

1. Kecamatan Palangka di Pahandut

2. Kecamatan Bukit Batu di Tengkiling

3. Kecamatan Rakumpit

4. Kecamatan Sebangau

5. Kecamatan Jekan Raya

Dengan disahkannya Undang-Undang Nomor 5 Tahun 1965, maka ditetapkanlah Kotapraja Palangkaraya yang otonom. Selanjutnya pada tanggal 17 Juni 1965 secara resmi menjadi Kotapraja Otonom Palangkaraya dengan Penguasa Kotapraja Palangkaraya adalah Gubernur Kepala Daerah Tingkat I Kalimantan Tengah (Bapak Tjilik Riwut), yang hingga saat ini momentum 17 Juni diperingati sebagai hari jadi Kota Palangkaraya. Kemudian pada tanggal 18 September 1965 dilantiklah Bapak Jantisaconk menjadi Walikota Kepala Daerah Kotapraja pertama.

Setelah era reformasi dengan terbitnya Undang-Undang Nomor 22 tahun 1999 tanggal 7 Mei 1999 tentang Pemerintahan Daerah, maka sebutan Kotamadya Daerah Tingkat II Palangkaraya berubah menjadi Daerah Kota Palangka Raya dan untuk sebutan Walikotamadya Kepala Daerah Tingkat II Palangka Raya menjadi Walikota Palangka Raya.

\section{Gambaran Jumlah mahjelis Taklim di Kota Palangka Raya}

Dari 5 (lima) kecamatan yang ada di kota Palangka Raya, jumlah pengajian yang ada sangat banyak dan bahkan lebih dari 100 buah, belum termasuk pengajian yang ada di organisasi keagamaan seperti Organisasi Nasyiatul Aisyiyah, Aisyiyah, IMM putri, Fatayat NU, Muslimat NU, Wanita Islam, Mar'atus Sholheh, Al Hidayah, Perwati, dan lain-lain, semua organisasi tersebut selalu melaksanakan pengajian rutinnya baik mingguan, bulanan (tergantung kesepakatan) untuk melihat data jumlah pengajian yang terdaftar di Kota Palangka Raya. 
E-ISSN : 2580-7056, ISSN : 2580-7064

Pascasarjana IAIN Palangka Raya

\section{Gambaran Umum Subjek}

Tabel 2

Subjek Penelitian

\begin{tabular}{|c|c|c|c|c|c|c|}
\hline \multirow[t]{2}{*}{ NO } & \multirow[t]{2}{*}{ INISIAL } & \multirow{2}{*}{$\begin{array}{l}\text { PENDIDIKAN } \\
\text { TERAKHIR } \\
\text { SUBJEK }\end{array}$} & PEKERJAAN & JUMLAH & \multicolumn{2}{|c|}{ (Yang diikuti Subjek) } \\
\hline & & & SUBJEK & Organisasi & $\begin{array}{l}\text { Pengajian } \\
\text { Mingguan }\end{array}$ & $\begin{array}{c}\text { Pengajian } \\
\text { Bulanan }\end{array}$ \\
\hline 1 & EL & Sarjana ( S1) & PNS & 2 & 3 & 2 \\
\hline 2 & SM & Sarjana (S2) & Guru & 3 & 2 & 1 \\
\hline 3 & $\mathrm{IH}$ & Sarjana (S1) & Guru & 2 & 2 & 1 \\
\hline 4 & NW & Diploma III & IRT & 5 & 2 & 2 \\
\hline 5 & SH & Sarjana (S1) & $\begin{array}{l}\text { Guru } \\
\text { Honor }\end{array}$ & 8 & 2 & 2 \\
\hline 6 & $M B$ & Sarjana (S1) & PNS & 7 & 3 & 3 \\
\hline 7 & SS & Sarjana (S1) & Wiraswasta & 4 & 2 & 4 \\
\hline 8 & $\mathrm{HD}$ & PGA & Swasta & 5 & 2 & 2 \\
\hline 9 & $\mathrm{HN}$ & SLTA & IRT & 7 & 3 & 3 \\
\hline 10 & $\mathrm{MH}$ & Sarjana (S2) & Guru & 5 & 1 & 4 \\
\hline 11 & HA & Sarjana (S1) & IRT & 2 & 1 & 4 \\
\hline 12 & KH & Sarjana (S1) & PNS & 2 & 3 & 2 \\
\hline 13 & $\mathrm{RH}$ & Sarjana (S2) & Honorer & 2 & 1 & 1 \\
\hline 14 & SA & Sarjana (S2) & PNS & 4 & 2 & 2 \\
\hline 15 & WS & Sarjana (S2) & Dosen & 4 & 3 & 2 \\
\hline
\end{tabular}

\section{G. Penyajian Data Hasil Penelitian}

Banyaknya ibu-ibu yang mengikuti pengajian di BKMT Kota Palangka Raya, sesuai dengan kreteria subjek yang penulis tuangkan di atas, maka diambillah 15 (lima belas) subjek yang mewakili dari 5 pengajian yang ada di Palangka Raya. Untuk lebih jelasnya dituangkan dalam sebuah tabel sebagai berikut :

1. Motivasi dan Faktor-faktor subjek dalam mengikuti pengajian, penulis sajikan dalam bentuk tabel berikut ini :

Tabel 3

Motivasi Subjek

\begin{tabular}{|c|c|l|l|}
\hline No & Inisial & \multicolumn{1}{|c|}{ Termotivasi karena } & Keterangan \\
\hline $\mathbf{1}$ & $\mathbf{2}$ & \multicolumn{1}{|c|}{$\mathbf{3}$} & $\mathbf{4}$ \\
\hline 1 & EL & $\begin{array}{l}\text { Menuntut ilmu agama } \\
\text { Silaturrahmi dengan teman-teman } \\
\text { Adanya ketenangan Batin/Jiwa }\end{array}$ & $\begin{array}{l}\text { Wawancara } \\
\text { tanggal } 29 \\
\text { Juli } 2017\end{array}$ \\
\hline
\end{tabular}


E-ISSN : 2580-7056, ISSN : 2580-7064

Pascasarjana IAIN Palangka Raya

\begin{tabular}{|c|c|c|c|}
\hline 2 & SM & $\begin{array}{l}\text { Menambah silaturrahmi } \\
\text { Menambah ilmu pengetahuan } \\
\text { Menambah wawasan keagamaan }\end{array}$ & $\begin{array}{l}\text { Wawancara } \\
\text { tanggal } 30 \\
\text { Juli } 2017\end{array}$ \\
\hline 3 & $\mathrm{IH}$ & $\begin{array}{l}\text { Menambah wawasan ilmu } \\
\text { pengetahuan } \\
\text { Menjalin silaturrahmi untuk memrerat } \\
\text { tali silaturrahmi } \\
\text { Meningkatkan keimanan dan } \\
\text { ketaqwaan }\end{array}$ & $\begin{array}{l}\text { Wawancara } \\
\text { tanggal } 31 \\
\text { Juli } 2017\end{array}$ \\
\hline 4 & NW & $\begin{array}{l}\text { Menjalin hubungan tali silaturrahmi } \\
\text { Menambah wawasan pengetahuan } \\
\text { agama } \\
\text { Bisa berbagi ilmu dan pengalaman }\end{array}$ & $\begin{array}{l}\text { Wawancara } \\
\text { tanggal } 3 \\
\text { Agustus } \\
2017\end{array}$ \\
\hline 5 & $\mathrm{SH}$ & $\begin{array}{l}\text { Menjalin silaturrahmi } \\
\text { Mencari pengalaman } \\
\text { Wadah berbagi ilmu dan informasi }\end{array}$ & $\begin{array}{l}\text { Wawancara } \\
\text { tanggal } 5 \\
\text { Agustus } \\
2017 \\
\end{array}$ \\
\hline 6 & $\mathrm{MB}$ & $\begin{array}{l}\text { Menjalin persaudaraan \& silaturrahmi } \\
\text { Menambah ilmu pengetahuan } \\
\text { Menambah amal ibadah }\end{array}$ & $\begin{array}{l}\text { Wawancara } \\
\text { tanggal } 7 \text { Agt } \\
2017\end{array}$ \\
\hline 7 & SS & $\begin{array}{l}\text { Belajar ilmu agama } \\
\text { Menambah sahabat } \\
\text { Menjalin silaturrahmi } \\
\text { Sebagai ibadah }\end{array}$ & $\begin{array}{l}\text { Wawancara } \\
\text { tanggal } 8 \text { Agt } \\
2017\end{array}$ \\
\hline 8 & HD & $\begin{array}{l}\text { Menjalin silaturrahmi } \\
\text { Muzakarah bil ma'ruf } \\
\text { Kegiatan social dan taklim }\end{array}$ & $\begin{array}{l}\text { Wawancara } \\
\text { tanggal } 13 \\
\text { Agtustus } \\
2017\end{array}$ \\
\hline 9 & HN & $\begin{array}{l}\text { Menuntut ilmu } \\
\text { Menjalin sikaturrahmi } \\
\text { Berbagi ilmu dengan keluarga }\end{array}$ & $\begin{array}{l}\text { Wawancara } \\
\text { tanggal } 14 \\
\text { Agustus } 2017\end{array}$ \\
\hline 10 & $\mathrm{MH}$ & $\begin{array}{l}\text { Menambah wawasan ke ilmuan } \\
\text { Menjalin tali silaturrahmi } \\
\text { Memanfatkan umur / sisa hidup }\end{array}$ & $\begin{array}{l}\text { Wawancara } \\
\text { tanggal } 15 \\
\text { Agustus } \\
2017\end{array}$ \\
\hline 11 & $\mathrm{HA}$ & $\begin{array}{l}\text { Memperbanyak teman dan bisa } \\
\text { siaturrahmi }\end{array}$ & $\begin{array}{l}\text { Wawancara } \\
\text { tanggal } 16 \\
\text { Agustus } 2017\end{array}$ \\
\hline 12 & $\mathrm{KH}$ & $\begin{array}{l}\text { Mempererat silaturrahmi } \\
\text { Menambah ilmu agama }\end{array}$ & $\begin{array}{l}\text { Wawancara } \\
\text { tanggal } 20 \\
\text { Agustus } \\
2017\end{array}$ \\
\hline
\end{tabular}


E-ISSN : 2580-7056, ISSN : 2580-7064

Pascasarjana IAIN Palangka Raya

\begin{tabular}{|c|c|l|l|}
\hline 13 & RH & $\begin{array}{l}\text { Menjalin silaturrahmi } \\
\text { Menambah ilmu pengetahuan }\end{array}$ & $\begin{array}{l}\text { Wawancara } \\
\text { tanggal 22 } \\
\text { Agustus } \\
2017\end{array}$ \\
\hline 14 & SA & $\begin{array}{l}\text { Menjalin silaturrahmi } \\
\text { Menambah pengetahuan tentang } \\
\text { keagamaan }\end{array}$ & $\begin{array}{l}\text { Wawancara } \\
\text { tanggal 23 } \\
\text { Agustus } \\
2017\end{array}$ \\
\hline 15 & WS & $\begin{array}{l}\text { Menambah wawasan keagamaan } \\
\text { Menjalin ukhuwah iskamiyah }\end{array}$ & $\begin{array}{l}\text { Wawancara } \\
\text { tanggal 24 } \\
\text { Agustus 2017 }\end{array}$ \\
\hline
\end{tabular}

Tabel 4

Faktor subjek antusias dalam mengikuti pengajian

\begin{tabular}{|c|c|c|c|}
\hline No & Inisial & Faktor Intern & Faktor Ekstren \\
\hline 1 & 2 & $\mathbf{3}$ & 4 \\
\hline 1 & EL & $\begin{array}{l}\text { Sarjana S1 } \\
\text { Pekerjaan PNS }\end{array}$ & Di ajak orang lain/teman \\
\hline 2 & SM & $\begin{array}{l}\text { Sarjana S2 } \\
\text { Pekerjaan Guru } \\
\text { Keinginan sendiri }\end{array}$ & Judul materi manarik \\
\hline 3 & $\mathrm{IH}$ & $\begin{array}{l}\text { Sarjana S1 } \\
\text { Pekerjaannya Guru } \\
\text { Keinginan sendiri }\end{array}$ & Materinya menarik \\
\hline 4 & NW & $\begin{array}{l}\text { Diploma } 3 \\
\text { Ibu Rumah Tangga }\end{array}$ & $\begin{array}{l}\text { Diajak orang lain } \\
\text { Materinya menyejukkan } \\
\text { Metodenya bagus }\end{array}$ \\
\hline 5 & $\mathrm{SH}$ & $\begin{array}{l}\text { Sarjana S1 } \\
\text { Guru } \\
\text { Keinginan sendiri }\end{array}$ & $\begin{array}{l}\text { Metodenya sesuai } \\
\text { Penceramahnya bagus }\end{array}$ \\
\hline 6 & $\mathrm{MB}$ & $\begin{array}{l}\text { Sarjana S1 } \\
\text { PNS } \\
\text { Keinginan sendiri }\end{array}$ & $\begin{array}{l}\text { Materi nya bagus } \\
\text { Metodenya baik }\end{array}$ \\
\hline 7 & SS & $\begin{array}{l}\text { Sarjana S1 } \\
\text { Wiraswasta } \\
\text { Keinginan sendiri }\end{array}$ & $\begin{array}{l}\text { Materi yang disukai Fiqih } \\
\text { wanita }\end{array}$ \\
\hline 8 & HD & $\begin{array}{l}\text { PGA } \\
\text { Swasta }\end{array}$ & $\begin{array}{l}\text { Diajak orang lain, materi } \\
\text { bagus }\end{array}$ \\
\hline 9 & $\mathrm{HN}$ & $\begin{array}{l}\text { SLTA } \\
\text { Ibu Rumah Tangga } \\
\text { Keinginan sendiri }\end{array}$ & $\begin{array}{l}\text { Materinya bagus, } \\
\text { Metodenya bagus } \\
\text { Penceramahnya } \\
\text { Profisional }\end{array}$ \\
\hline
\end{tabular}


E-ISSN : 2580-7056, ISSN : 2580-7064

Pascasarjana IAIN Palangka Raya

\begin{tabular}{|c|c|l|l|}
\hline 10 & MH & $\begin{array}{l}\text { Sarjana S2 } \\
\text { Guru } \\
\text { Keinginan sendiri }\end{array}$ & $\begin{array}{l}\text { Terpengaruh dengan } \\
\text { teman-teman, materi } \\
\text { cukup bagus }\end{array}$ \\
\hline 11 & HA & $\begin{array}{l}\text { Sarjana S1 } \\
\text { Ibu Rumh Tangga } \\
\text { Keinginan sendiri }\end{array}$ & $\begin{array}{l}\text { Materi nya menarik } \\
\text { Metodenya bagus } \\
\text { Da'inya professional }\end{array}$ \\
\hline 12 & KH & $\begin{array}{l}\text { Sarjana S1 } \\
\text { PNS }\end{array}$ & $\begin{array}{l}\text { Diajak Sahabat/orang } \\
\text { lain Materi } \\
\text { menyenagkan } \\
\text { Metodenya cocok }\end{array}$ \\
\hline 13 & RH & $\begin{array}{l}\text { Sarjana S2 } \\
\text { Honorer }\end{array}$ & $\begin{array}{l}\text { Diajak oleh orang lain } \\
\text { Materinya bagus }\end{array}$ \\
\hline 14 & SA & $\begin{array}{l}\text { Sarjana S2 } \\
\text { PNS }\end{array}$ & $\begin{array}{l}\text { Diajak orang lain } \\
\text { Materinya menarik } \\
\text { Metodenya bagus }\end{array}$ \\
\hline 15 & WS & $\begin{array}{l}\text { Sarjana S2 } \\
\text { Dosen } \\
\text { Membentuk pengajian } \\
\text { sendiri }\end{array}$ & $\begin{array}{l}\text { Materinya bagus } \\
\text { Metodenya sesuai } \\
\text { Penceramahnya } \\
\text { profesionl }\end{array}$ \\
\hline
\end{tabular}

Tabel 5

Materi dan Metode yang digunakan Penceramah

\begin{tabular}{|c|c|c|c|}
\hline No & Inisial & $\begin{array}{c}\text { Materi yang disukai } \\
\text { subjek }\end{array}$ & Metode yang disukai subjek \\
\hline 1 & 2 & $\mathbf{3}$ & $\mathbf{3}$ \\
\hline 1 & EL & Fiqih Wanita & $\begin{array}{l}\text { Ceramah, Tanya jawab (sesuai } \\
\text { materi yang disampaikan), } \\
\text { demonstrasi }\end{array}$ \\
\hline 2 & SM & Fiqh & $\begin{array}{lll}\text { Ceramah, } & \text { Tanya jawab, } \\
\text { demonstrasi } & & \\
\end{array}$ \\
\hline 3 & $\mathrm{IH}$ & $\begin{array}{l}\text { Sholat, Muamalah, } \\
\text { Akhlak tercela }\end{array}$ & Ceramah, Tanya jawab (Dialog) \\
\hline 4 & NW & $\begin{array}{l}\text { Iman, Islam dan Ihsan } \\
\text { Akhlakul Karimah } \\
\text { Keutamaan sholawat }\end{array}$ & Ceramah, Tanya Jawab \\
\hline 5 & $\mathrm{SH}$ & Fiqih, Tauhid dan Akhlak & Ceramah, Tanya jawab \\
\hline 6 & $\mathrm{MB}$ & Aqidah dan Ibadah & Ceramah, Tanya Jawab \\
\hline 7 & SS & Fiqih Wanita & $\begin{array}{l}\text { Ceramah, Tanya Jawab, Peragaan/ } \\
\text { demonstrasi }\end{array}$ \\
\hline 8 & HD & $\begin{array}{l}\text { Aqidah, pendidikan, } \\
\text { syari'ah dan dakwah }\end{array}$ & Ceramah, Tanya Jawab \\
\hline 9 & $\mathrm{HN}$ & Fiqih dan Ahklak & Ceranah, Tanya Jawab \\
\hline
\end{tabular}


E-ISSN : 2580-7056, ISSN : 2580-7064

Pascasarjana IAIN Palangka Raya

\begin{tabular}{|l|c|l|l|}
\hline 10 & MH & $\begin{array}{l}\text { Pendidikan, Munakahat, } \\
\text { tentang } \\
\text { sakinah }\end{array}$ & Ceramah, Tanya Jawab \\
\hline 1 & 2 & \multicolumn{1}{|c|}{3} & \multicolumn{1}{|c|}{4} \\
\hline 11 & HA & Pendidikan Anak & Ceramah, Tanya jawab \\
\hline 12 & KH & Fiqih dan Tauhid & Ceramah, Tanya Jawab \\
\hline 13 & RH & Fiqih dan Tauhid & Ceramah, Tanya jawab \\
\hline 14 & SA & $\begin{array}{l}\text { Sholat dan hak serta } \\
\text { kewajiban terhadap } \\
\text { tetangga }\end{array}$ & Ceramah, Tanya Jawab \\
\hline 15 & WS & $\begin{array}{l}\text { Fiqih wanita dan Tata } \\
\text { cara sholat yang benar }\end{array}$ & Ceramah, Tanya Jawab \\
\hline
\end{tabular}

Tabel 6

Penceramah yang diinginkan subjek

\begin{tabular}{|c|c|c|c|}
\hline \multirow[b]{2}{*}{ No } & \multirow[b]{2}{*}{ Inisial } & \multicolumn{2}{|c|}{ Penceramah } \\
\hline & & Laki-laki & Perempuan \\
\hline 1 & EL & $\checkmark$ & \\
\hline 2 & SM & & 1 \\
\hline 3 & $\mathrm{IH}$ & & $\varphi$ \\
\hline 4 & NW & & 1 \\
\hline 5 & $\mathrm{SH}$ & & 1 \\
\hline 6 & MB & & 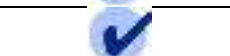 \\
\hline 7 & SS & & 4 \\
\hline 8 & HD & & $C$ \\
\hline 9 & $\mathrm{HN}$ & & 1 \\
\hline 10 & $\mathrm{MH}$ & $\nu$ & 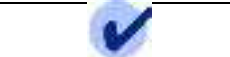 \\
\hline 11 & HA & & 1 \\
\hline 12 & $\mathrm{KH}$ & & 1 \\
\hline 13 & RH & & 1 \\
\hline 14 & SA & & $c$ \\
\hline 15 & WS & $\nu$ & \\
\hline
\end{tabular}

Tabel 7

Waktu yang sesuai untuk Pengajian

\begin{tabular}{|l|c|c|c|c|c|}
\hline \multirow{3}{*}{ No } & \multirow{3}{*}{ Inisial } & \multicolumn{4}{|c|}{ Waktu yang tepat } \\
\cline { 3 - 5 } & Pagi & Siang & Sore & Malam \\
\hline
\end{tabular}


E-ISSN : 2580-7056, ISSN : 2580-7064

Pascasarjana IAIN Palangka Raya

\begin{tabular}{|c|c|c|c|c|c|}
\hline 1 & $\mathrm{EL}$ & & & & \\
\hline 2 & $\mathrm{SM}$ & & & & \\
\hline 3 & $\mathrm{IH}$ & & & & \\
\hline 4 & $\mathrm{NW}$ & & & & \\
\hline 5 & $\mathrm{SH}$ & & & & \\
\hline 6 & $\mathrm{MB}$ & & & & \\
\hline 7 & $\mathrm{SS}$ & & & $\checkmark$ & \\
\hline 8 & $\mathrm{HD}$ & & & & \\
\hline 9 & $\mathrm{HN}$ & & & & \\
\hline 10 & $\mathrm{MH}$ & & & & \\
\hline 11 & $\mathrm{HA}$ & & & & \\
\hline 12 & $\mathrm{KH}$ & & & & \\
\hline 13 & $\mathrm{RH}$ & & & & \\
\hline 14 & $\mathrm{SA}$ & & & & \\
\hline 15 & $\mathrm{HS}$ & & & & \\
\hline
\end{tabular}

Tabel 8

Tempat pengajian yang digunakan

\begin{tabular}{|c|c|c|c|c|c|}
\hline \multirow[b]{2}{*}{ No } & \multirow[b]{2}{*}{ Inisial } & \multicolumn{4}{|c|}{ Tempat yang digunakan } \\
\hline & & Masjid & Mushalla & Rumah & Aula \\
\hline 1 & EL & 4 & & & \\
\hline 2 & SM & $\checkmark$ & & & \\
\hline 3 & $\mathrm{IH}$ & $\checkmark$ & & & \\
\hline 4 & NW & 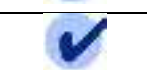 & $V$ & $V$ & $V$ \\
\hline 5 & $\mathrm{SH}$ & 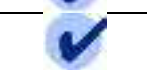 & $v$ & $V$ & $V$ \\
\hline 6 & $\mathrm{MB}$ & 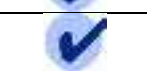 & & & \\
\hline 7 & SS & & & & $V$ \\
\hline 8 & HD & 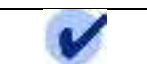 & & & \\
\hline 9 & $\mathrm{HN}$ & 4 & & & \\
\hline 10 & $\mathrm{MH}$ & 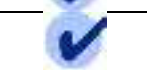 & & $V$ & \\
\hline 11 & HA & $V$ & & $\checkmark$ & \\
\hline 12 & $\mathrm{KH}$ & & & $V$ & \\
\hline 13 & $\mathrm{RH}$ & 1 & & & \\
\hline 14 & SA & & & & $V$ \\
\hline 15 & WS & & & & \\
\hline
\end{tabular}


E-ISSN : 2580-7056, ISSN : 2580-7064

Pascasarjana IAIN Palangka Raya

2. Implikasi Ibu-ibu setelah mengikuti pengajian di BKMT Kota Palangka Raya

Untuk mengetahui implikasi ibu-ibu setelah pengajian, maka dapat dilihat dalam tabel berikut :

Tabel 9

Implikasi Subjek setelah mengikuti Pengajian

\begin{tabular}{|c|c|c|c|}
\hline No & Inisial & Implikasi Subjek & Keterangan \\
\hline 1 & 2 & 3 & 4 \\
\hline 1 & EL & $\begin{array}{l}\text { Rajin Bersedekah } \\
\text { Sering membaca Al Qur'an } \\
\text { Suka memberi nasehat dengan kawan }\end{array}$ & $\begin{array}{l}\text { Wawancara } \\
\text { tanggal } 29 \\
\text { Juli } 2017\end{array}$ \\
\hline 2 & SM & $\begin{array}{l}\text { Mengerti Tata Cara mendidik anak yang } \\
\text { sesuai dengan ajaran Islam }\end{array}$ & $\begin{array}{l}\text { Wawancara } \\
\text { tanggal } 30 \\
\text { Juli } 2017\end{array}$ \\
\hline 3 & $\mathrm{IH}$ & $\begin{array}{l}\text { Belajar melaksanakan sholat malam } \\
\text { Berusaha melaksanakan sholat Dhuha }\end{array}$ & $\begin{array}{l}\text { Wawancara } \\
\text { tanggal } 31 \\
\text { Juli } 2017\end{array}$ \\
\hline 4 & NW & $\begin{array}{l}\text { Suka berbagi pengalaman dengan } \\
\text { kawan } \\
\text { Belajar mengamalkan puasa sunat } \\
\text { (sunat Syawal) }\end{array}$ & $\begin{array}{l}\text { Wawancara } \\
\text { tanggal } 3 \\
\text { Agustus } \\
2017\end{array}$ \\
\hline 5 & SH & $\begin{array}{l}\text { Sering kumpul-kumpul dengan kawan } \\
\text { sambil membahas pelajaran agama }\end{array}$ & $\begin{array}{l}\text { Wawancara } \\
\text { tanggal } 5 \\
\text { Agustus } \\
2017\end{array}$ \\
\hline 6 & MB & $\begin{array}{l}\text { Suka berkunjung ke tempat keluarga } \\
\text { Mengamalkan bacaan zikir-zikir }\end{array}$ & $\begin{array}{l}\text { Wawancara } \\
\text { tanggal } 7 \text { Agt. } \\
2017\end{array}$ \\
\hline 7 & SS & $\begin{array}{l}\text { Suka berbagi rizqi dengan orang yang } \\
\text { memerlukan (bersedekah) } \\
\text { Lebih memahami tentang masalah } \\
\text { kewanitaan } \\
\text { Rasa aman, tenang, tentram }\end{array}$ & $\begin{array}{l}\text { Wawancara } \\
\text { tanggal } 8 \text { Agt } \\
2017\end{array}$ \\
\hline 8 & HD & $\begin{array}{l}\text { Suka mengumpul kawan-kawan untuk } \\
\text { belajar agama }\end{array}$ & $\begin{array}{l}\text { Wawancara } \\
\text { tanggal } 13 \\
\text { Agtustus } \\
2017\end{array}$ \\
\hline 9 & $\mathrm{HN}$ & Lebih mudah memberikaan pendidikan & Wawancara \\
\hline
\end{tabular}


E-ISSN : 2580-7056, ISSN : 2580-7064

Pascasarjana IAIN Palangka Raya

\begin{tabular}{|c|c|l|l|}
\hline & & $\begin{array}{l}\text { agama kepada anak tanpa paksaan } \\
\text { Tambah kasih saying }\end{array}$ & $\begin{array}{l}\text { tanggal 14 } \\
\text { Agustus 2017 }\end{array}$ \\
\hline 10 & MH & $\begin{array}{l}\text { Sering membaca Al Qur'an dan } \\
\text { berusaha mempelajari maknanya } \\
\text { Mengerti tata cara membentuk } \\
\text { keluarga sakinah mawaddah warahmah }\end{array}$ & $\begin{array}{l}\text { Wawancara } \\
\text { tanggal 15 } \\
\text { Agustus } \\
2017\end{array}$ \\
\hline 11 & HA & $\begin{array}{l}\text { Berusaha memahami karakteristik } \\
\text { kawan } \\
\text { Lebih sabar dalam menghadapi } \\
\text { keluarga (anak dan suami) }\end{array}$ & $\begin{array}{l}\text { Wawancara } \\
\text { tanggal 16 } \\
\text { Agustus 2017 }\end{array}$ \\
\hline 12 & KH & $\begin{array}{l}\text { Mengamalkan bacaan sholawat dan } \\
\text { amalan yag lainnya }\end{array}$ & $\begin{array}{l}\text { Wawancara } \\
\text { tanggal 20 } \\
\text { Agustus } \\
2017\end{array}$ \\
\hline 13 & RH & $\begin{array}{l}\text { Memberikan nasehat kepada kawan } \\
\text { yang ada persoalan }\end{array}$ & $\begin{array}{l}\text { Wawancara } \\
\text { tanggal 22 } \\
\text { Agustus } \\
2017\end{array}$ \\
\hline 14 & SA & $\begin{array}{l}\text { Lebih sosial dan sering bersedekah } \\
\text { kepada orang yang memerlukan }\end{array}$ & $\begin{array}{l}\text { Wawancara } \\
\text { tanggal 23 } \\
\text { Agustus } \\
2017\end{array}$ \\
\hline WS & $\begin{array}{l}\text { Lebih suka mengamalkan yang praktis- } \\
\text { praktis khususnya kegiatan sehari-hari }\end{array}$ & $\begin{array}{l}\text { Wawancara } \\
\text { tanggal 24 } \\
\text { Agustus 2017 }\end{array}$ \\
\hline
\end{tabular}

\section{H. Analisis/ Pembahasan Penelitian}

Dalam analisis / pembahasan ini tidak akan lepas dari rumusan masalah yang penulis kemukan, yakni :

\section{Motivasi dan faktor-faktor yang menyebabkan subjek antusias dalam mengikuti pengajian}

Motivasi merupakan dorongan dalam diri seseorang untuk melakukan atau yang dapat menggerakkan dan mengarahkan tingkah laku atau perbutan seseorang untuk mencapai suatu tujuan. Motivasi dirancang karena ada tujuan, yakni merupakan respon dari satu aksi, yang muncul dari diri seseorang karena terangsang atau terdorong oleh adanya unsur lain.

Dalam Al Qur'an Surah Ar-Ra'd ayat 11 menggambarkan, bahwa ayat tersebut ternyata motivasi yang paling kuat adalah dari diri seseorang. Motivasi sangat berpengaruh dalam gerak-gerik seseorang dalam setiap tindaktanduknya. Apabila dikaitkan dengan tingkah laku keagamaan, maka motivasi tersebut penting untuk dibicarakan sebab akan dapat mengetahui apa 
E-ISSN : 2580-7056, ISSN : 2580-7064

Pascasarjana IAIN Palangka Raya

sebenarnya yang melatar belakangi suatu tingkah laku keagaman yang dikerjakan seseorang.

Menurut Ramayulis, peran motivasi dalam kehidupan manusia .sangat banyak diantaranya :

1) Motivasi sebagai pendorong manusia dalam melakukan sesuatu, sehingga menjadi unsur penting dan tingkah laku atau tindakan manusia

2) Motivasi bertujuan untuk menentukan arah dan tujuan

3) Motivasi berfungsi sebagai penguji sikap manusia dalam beramal benar atau salah sehingga bisa dilihat kebenarannya dan kesalahannya

4) Motivasi berfungsi sebagai penyeleksi atas perbuatan yang akan dilakukan oleh manusia baik atau buruk. Jadi motivasi itu berfungsi sebagai pendorong, penentu, penyeleksi dan penguji sikap manusia dalam kehidupannya. ${ }^{20}$

Berdasarkan penyajian data dan hasil penelitian yang dipaparkan di atas, penulis membahas tentang motivsi ibu-ibu mengikuti pengajian di BKMT Kota Palangka Raya.

Pada kenyataannya motivasi ibu-ibu mengikui pengajian sangat antusias, seperti pengajian rutin seminggu satu kali ada juga seminggu beberapa kali, dan bahkan ada pengajian rutin sebulan sekali terkadang ada beberapa kali dalam sebulan (lihat tabel 1), hal itu bisa terlihat dengan jawaban subjek yang dipaparkan di atas, mereka termotivasi untuk mengikuti pengajian, karena menuntut ilmu agama dan juga menambah wawasan keagamaan. Untuk itu, agama tidak cukup dipahami hanya secara legal formalistik ritualistik saja, akan tetapi harus digali dan dipahami secara substantif.

Menurut Prof. Dr.Hj. Tutty Alawiyah mengatakan : Agama yang berupa teks-teks kitab suci tidak bisa ditelan mentah-mentah, tetapi diperlukan pengolahan dan interpretasi yang bersifat kontekstual dan fungsional saja, tetapi agama diharapkan dapat berperan dan merespon persoalan-persoalan yang dihadapi. $^{21}$

Menuntut ilmu itu wajib bagi setiap muslim dan muslimah (hadis Rasul). Allah berfirman dalam Al Qur' an (surah Al Isra ayat 36) sebagai berikut :

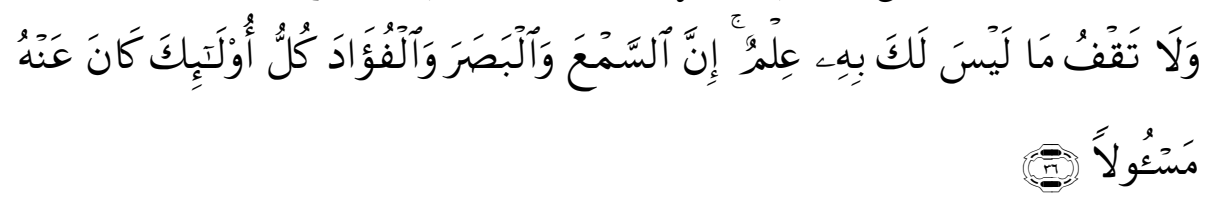

Artinya:

\footnotetext{
${ }^{20}$ Ramayulis, Psikologi Agama,(Jakarta : Kalam Mulia, 2011), h. 102

${ }^{21}$ Tutty Alawiyah, The Inspiring Woman Penggerak Kemajuan dan Peradaban, ( Jakarta Timur : UIA Press, 2012) h. 61 
"dan janganlah kamu mengikuti apa yang kamu tidak mempunyai pengetahuan tentangnya. Sesungguhnya pendengaran, penglihatan dan hati, semuanya itu akan diminta pertanggungan jawabnya".

Selanjutnya dalam surah Al Mujadalah ayat 11 sebagai berikut :

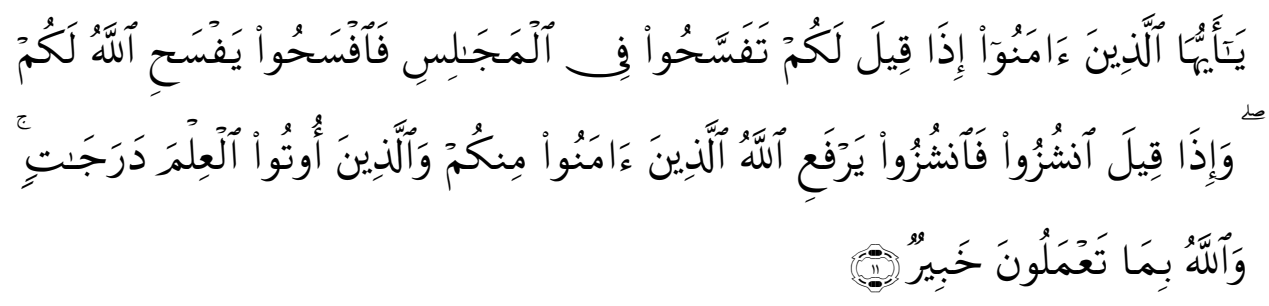

“ Hai orang-orang beriman apabila kamu dikatakan kepadamu: "Berlapang-lapanglah dalam majlis", Maka lapangkanlah niscaya Allah akan memberi kelapangan untukmu. dan apabila dikatakan: "Berdirilah kamu", Maka berdirilah, niscaya Allah akan meninggikan orang-orang yang beriman di antaramu dan orang-orang yang diberi ilmu pengetahuan beberapa derajat. dan Allah Maha mengetahui apa yang kamu kerjakan.”

Selain termotivasi untuk menuntut ilmu para subjek juga mengatakan termotivasi untuk menjalin tali silaturrahmi dan ukhuwah Islamiyah. Sebagai manusia kita menjadi hamba yang taat kepada Allah SWT, taqwa yang sebenarbenarnya taqwa menjaga hubungan baik dengan Allah SWT dan menjaga hubungan baik dengan sesama manusia, Allah SWT mencintai hamba-Nya yang taat dan menjaga tali silaturahmi. Menyambung silaturahmi merupakan suatu amal shaleh yang penuh berkah, memberikan kepada pelakunya kebaikan di dunia dan akhirat, menjadikannya ia dicintai Allah SWT di manapun ia berada.

Menurut Achmad Sunarto, diantara hikmah menjaga silaturahmi adalah

1) Menjadikan seorang hamba lebih dekat dengan Allah SWT dan dicintai Allah SWT, hati akan terasa tanang, damai dan tentram.

2) Insha Allah meluaskan rezeki, dari sisi psikologis hidup tentram akan menjadikan jiwa menjadi lebih sehat, Insha Allah jika Allah berkendak umur kita akan diopanjangkan. Allah SWT maha kuasa atas segala sesuatu.

3) Di senangi para malaikat, karena malaikat juga senang bersilaturahmi.

4) Di benci shaiton, mereka akan lebih sulit untuk menyesatkan kita, karena kita menjadi lebih dekat dengan Allah SWT. Sesungguhnya shaiton adalah musuh yang nyata bagi manusia. Teruslah mendekat 
E-ISSN : 2580-7056, ISSN : 2580-7064

Pascasarjana IAIN Palangka Raya

kepada Allah SWT agar kita selalu terlindungi dari gangguan aduwumubin tersebut.

5) Lebih mudah hidup dimasyarakat, di senangi manusia dan bisa memupuk rasa cinta kasih dan rasa peduli antar sesama manusia.

6) Terbentukanya ukhuwah Islamiah yang insha Allah penuh berkah dan sama-sama mendapat rahmati Allah SWT. ${ }^{22}$

Subjek WS mengatakan selain menjalin hubungan silaturrahmi juga termotivasi untuk menjalin Ukhuwah Islamiyah sesama muslim dengan menjalin keterikatan hati dan jiwa satu sama lain dengan ikatan aqidah

Hal-hal yang menguatkan Ukhuwah Islamiyah adalah :

1) Memberitahukan kecintaan pada yang kita cintai

2) Memohon dido'akan bila berpisah

3) Menunjukkan kegembiraan \& senyuman bila berjumpa

4) Berjabat tangan bila berjumpa

5) Mengucapkan selamat berkenaan dengan saat-saat keberhasilan

6) Memberikan hadiah pada waktu-waktu tertentu

7) Sering bersilaturahmi (mengunjungi saudara)

8) Memperhatikan saudaranya \& membantu keperluannya. ${ }^{23}$

Seperti itulah persaudaraan sesama Muslim atau ukhuwah Islamiyah. Persaudaraan yang penuh dengan ketulusan dan keikhlasan.

Salah seorang subjek MH, mengatakan : Dia termotivasi mengikuti pengajian dikarenakan memanfaatkan sisa umur yang diberikan oleh Alah SWT. Karna dia merasa kematian adalah suatu keniscayaan tidak satu jiwapun mampu menghindarinya. Hidup didunia hanya sesaat dan kehidupan akhirat lebih mulia, lebih utama dan abadi. Dengan kesadaran seperti itu MH memilih ke jalan spiritual dengan salah satunya mengikuti pengajian.

Hal senada yang diungkapkan oleh Komaruddin Hidayat dalam buku Psikologi Kematian ; "Seseorang yang menjalankan agama sebagai rujukan bahwa keabadian setelah mati pasti ada dan untuk memperoleh kebahagian abadi, seseorang yang religious menjadikan kehidupan akhirat sebagai objek dan target yang paling tinggi". ${ }^{24}$

Bukan seperti aliran Hedonisme yang merupakan salah suatu aliran di dalam filsafat yang memandang bahwa tujuan hidup yang utama pada manusia adalah mencari kesenangan (hedone) yang bersifat duniawi. Hedonisme adalah bahasa Yunani yang berarti kesukaan, kesenangan, atau kenikmatan. Menurut

\footnotetext{
${ }^{22}$ Sunarto, Bekal Dakwah dan Pembina Pribadi Muslim, (Jakarta : Setia Kawan, 2002), h. 21

${ }^{23}$ Husni Adham, Bercinta dan bersaudara karena Allah, (Jakarta : 2011), h. 13

${ }^{24}$ Komarudin Hidayat, Psikologi Kematian, (Jakarta : PT Mizan Publika, 2009), h. 17
} 
E-ISSN : 2580-7056, ISSN : 2580-7064

Pascasarjana IAIN Palangka Raya

pandangan hedonisme, manusia pada hakikatnya adalah makhluk yang mementingkan kehidupan yang penuh kesenangan dan kenikmatan. ${ }^{25}$

Selanjutnya menurut Subjek EL, mengikuti pengajian yang dilaksanakan ibu-ibu, dapat menenangkan batin dan jiwa sebagai tujuan utamanya, di merasakan adanya kepuasan hati, ketenteraman hidup, dan ketenangan jiwa, ketika mendengarkan ceramah yang disampai oleh para ustaz dan ustazah. halhal yang bisa mendatangkan dan menimbulkan kepuasan hati, ketenteraman hidup dan ketenangan jiwa yang banyak digemari orang saat ini, pada kenyataannya tidak mungkin dapat dipisahkan dari praktek ibadah, bahkan sangat berkaitan erat dengan masalah aqidah yang letaknya di dalam hati, sedangkan hati merupakan sumber dari kebaikan atau keburukan seseorang.

Menurut Zafar Afaq, mengungkapkan : " Para ulama muslim telah menginterpretasikan hati sebagai cahaya spiritual lembut yang bagaimanapun mempunyai imbangan fungsinya dalam gumpalan daging berbentuk kerucut itulah yang disebut dengan hati" ${ }^{26}$

Selain motivasi ibu-ibu mengikuti pengajian tentunya tidak akan terlepas dari faktor-faktor yang menyebabkan ibu-ibu antusias mengikuti pengajian.pengajian tersebut. Untuk membahas faktor-faktor yang menyebabkan ibu-ibu sangat antusias mengikuti pengajian, tentunya tidak terlepas dari 2 (dua) factor Intern dan Ekstren. Adapun faktor Intern yang meliputi penddikan, pekerjaan dan minat seseorang. Pada dasarnya sebahagian subjek mengikuti pengajian karena atas keinginan sendiri, namun ada juga sebagian subjek ikut pengajian karena ajakan dari orang lain.

Pendidikan seseorang cukup berpengaruh terhadap faktor-faktor motivasi seseorang untuk mengikuti pengajian. Dalam hal ini semua subjek yang diteliti mempunyai pendidikan yang cukup bagus, dan bahkan ada yang sampai S2. Jadi kesadaran untuk menuntut ilmu agama sangat kuat. Pendidikan merupakan hal yang sangat penting untuk manusia karena dapat menciptakan manusia yang berkualitas, berintelektual dan jauh dari kebodohan.

Manusia yang berpendidikan atau berilmu tentu berbeda dari manusia yang tidak berpendidikan atau tidak berilmu. Kita dapat membedakannya dari cara bersikap, bertutur, cara berpikir dan menjaga emosi. Dibawah ini adalah beberapa manfaat yang didapat dari pendidikan adalah :

1) Memberikan ilmu pengetahuan, pemahaman dan pengalaman adalah untuk memberikan informasi, meningkatkan ilmu pengetahuan, membantu untuk memahami ilmu pengetahuan yang selalu berkembang, dan memberikan pengalaman untuk bekal dalam menjalani pekerjaan dengan baik .

\footnotetext{
${ }^{25}$ Ngalim Purwanto, Psikologi Pendidikan, Bandung: PT Remaja Rosdakarya, 2007, h. 74

${ }^{26}$ Zafar Afaq, Al Qur'an Bicara tentang Jiwa, (Bandung : Penerbit Arasy, 2003), h. 49 
2) Mengembangkan talenta adalah sarana untuk mencari dan mengembangkan Talenta yang sudah Tuhan anugerahkan pada setiap individu.

3) Membentuk dan memperbaiki pola pikir karena Seiring bertambahnya informasi, ilmu pengetahuan dan pengalaman tentunya akan berpengaruh dalam peningkatan cara berpikir, kemampuan menganalisa dan daya imajinasi

4) Memberikan taraf kehidupan yang baik dengan mengenyam pendidikan maka kemampuan dalam bekerja pun didapat dan dapat terus berkembang hal ini akan memberikan kesempatan kerja dan penghasilan yang baik

5) Membangun bangsa karena Individu yang mengenyam pendidikan mendapatkan kepribadian yang terbentuk dengan baik dan ilmu pengetahuan yang bertambah, kesempatan kerja dan kesempatan mendapat penghasilan yang baik akan membantu menciptakan generasi yang baik. $^{27}$

Selain faktor pendidikan di atas, faktor pekerjaan juga cukup menentukan dalam melaksanakan kegiatan pengajian. Bagi sesorang yang sangat sibuk dengan pekerjaannya, akan jarang bisa mengikuti pengajian yang ada di tempat tinggalnya, hal ini senada dengan sunjek $\mathrm{RH}$, walaupun dian sudah berpendidikan S2, tapi disibukkan dengan pekerjaan sehari-harinya sebagai tenaga honorer, selain itu waktu dan kesemptan bagi seseorang sangat menentukan.

Islam menempatkan bekerja sebagai ibadah untuk mencari rezeki dari Allah guna menutupi kebutuhan hidupnya. Bekerja untuk mendapatkan rezeki yang halalan thayiban termasuk kedalam jihad di jalan Allah yang nilainya sejajar dengan melaksanakan rukun Islam. Dengan demikian bekerja adalah ibadah dan menjadi kebutuhan setiap umat manusia. Bekerja yang baik adalah wajib sifatnya dalam Islam. ${ }^{28}$

Selanjutnya hampir semua subjek mempunyai minat sendiri dan juga atas bantuan orang lain yang akhirnya berminat untuk menuntut ilmu pengetahuan pada pengajian ibu-ibu.

Adapun materi yang diberikan oleh para dai/daiyah bervariasi, ada masalah Fiqih/Fiqih wanita, Aqidah, Akhlak, Syariah, Pendidikan anak dan masalah Keluarga Sakinah.

Para subjek sangat menyenangi pembelajaran Fiqih wanita, seperti yang diutarakan oleh subjek SS, subjek HN, apabila penceramahnya perempuan, maka para subjek leluasa untuk bertanya, karena banyak sekali hal-hal yang berhubungan dengan wanita, yang tentunya agak malu/tidak terucapkan kalau di tanyakan dengan penceramah laki-laki, para ibu juga harus memiliki ilmu seperti halnya kaum laki-laki.

${ }^{27}$ Suharsono, Mencerdaskan Anak, (Jakarta : Inisiasi Pres, 2004), h. 11

${ }^{28}$ Komaruddin Hidayat, Psikologi Ibadah, (Jakarta : PT Serambi Ilmu Semesta, 2008), h. 24 
E-ISSN : 2580-7056, ISSN : 2580-7064

Pascasarjana IAIN Palangka Raya

Wanita memiliki andil dan tugas dalam menata dan memperbaiki masyarakat. Tidak ada keraguan lagi, untuk melaksanakan tanggung jawab dalam membina diri sendiri dan masyarakat, mutlak membutuhkan ilmu. Konsekuensinya, kaum wanita juga harus memiliki ilmu untuk menjalankan tanggung-jawab tersebut. Karenanya, ia bertanggung jawab penuh dalam pelaksanaan ibadah shalatnya, ibadah puasanya, pembayaran zakatnya, ibadah hajinya, usaha pemurnian aqidahnya, aktifitas amar ma'ruf nahi munkar dan semangat berlomba dalam setiap kebaikan. Ringkasnya, seluruh kandungan risalah Islam yang termaktub dalam Al-Qur'ân maupun Hadits tentang kewajiban seorang muslim, memiliki makna bahwa wanita juga berkewajiban untuk mempelajari dan mengajarkannya, baik secara teori maupun dalam amaliah nyata.

Selain Fiqih wanita, subjek juga sangat berkesan dengan materi Pembinaan keluarga sakinah, seperti yang diutarakan oleh subjek $\mathrm{MH}$, dia sangat menyenagi dengan materi yang disampaikan oleh ustaz dan ustazah, tentang bagaimana menjadi istri yang baik, bagaimana agar tetap romantis, walaupun sudah puluhan tahun berkeluarga, bagaimana cara berkomunikasi yang baik antara suami dan isteri.

Menurut Khoirudin Bashori dalam buku Psikologi Keluarga Sakinah, menjelaskan, bagaimana agar tetap romantis antara suami dan isteri, yakni sebagai berikut : "Pertama diabaikannya kejengkelan-kejengkelan atau kekesalan-kekesalan, Kedua selalu sediakan waktu khuus untuk berdua-duaan, ketiga lakukan kegiatan-kegiatan baru yang menyenagkan". ${ }^{29}$

Selanjutnya materi yang menjelaskan bagaimana cara suami istri berkomunikasi yang baik, dengan mencoba mengembangkan model komunikasi yang lebih sehat-konstruktif seperti jangan ngeyel dan ngambek, jangan menyalahkan atau menuduh antara suami isteri, belajar mendengarkan untuk memahami, jangan suka mengalihkan topik pembicaraan.

Semua materi yang diajarkan / yang diberikan ustaz/ustazah sangat disenangi oleh para subjek, apalagi diselingi dengan metode yang menyenangkan, seperti dilaksanakannya Tanya jawab atau dialog antara subjek dengan penceramah. Dari sebagian besar subjek menghendaki yang memberikan materi pengajian di tempat-tempat pengajian adalah para ustazah. Terlebih lagi ketika materi HAID, maka sangat cocok ustazah yang memberikannya karena ada hal-hal yang mungkin bagi penceramah laki-laki agak kurang enak dalam menyampaikan secara vulgar.

${ }^{29}$ Khoiruddin Bashori, Psikologi Keluarga Sakinah, (Yogyakarta : Penerbit Suara Muhammadiyah, 2006), h. 40 
E-ISSN : 2580-7056, ISSN : 2580-7064

Pascasarjana IAIN Palangka Raya

Namun masih ada subjek yang menginginkan penceramahnya laki-laki, dengan alasan laki-laki lebih berwibawa dan homoris, selain itu dalam memberikan materi lebih lugas dan tegas.

Semua materi yang disa sampaikan kepada para subjek, menurutnya memuaskan dan sangat bermanfaat, karena ilmu bertambah lebih mengetahu hukumnya karena disampaikan dalil-dalil naqli oleh para penceramah.

Adapun masalah tempat diadakannya pengajian tersebut fleksible saja, bisa di masjid, mushala, dirumah ataupun di aula. Biasanya acara tersebut sesuai dengan kesepakatan ibu-ibu pengajian pada saat acara pengajian. Semua subjek mengatakan bahwa sebagai tanda ikatan kekeluargaan, maka di pengajian di adakan arisan berkisar antara Rp. 10.000,- sampai dengan Rp. 25.000,- dalam seminggu/sesuai kesepakatan. Sedangkan waktu pelaksanaan pengajian menurut subjek antara siang dan sore hari.

\section{Implikasi ibu-ibu setelah mengikuti Pengajian}

Pengajian yang dilaksanakan ibu-ibu menempati posisi sentral dalam berjalannya suatu kelompok sosial, karena pengajian merupakan salah satu proses pentransferan (sosialisasi) nilaiatau norma-norma kelompok terhadap anggota lainnya. Pengajian juga dapat meningkatkan assobiyah (solidaritas) aggota dengan anggota lainnya, hubungan sesame anggota ibu-ibu sangat akrab atau intim, dan mereka telah mengenal secara baik sesame anggota.

Di dalam pengajian Ustaz adalah sebagai pengajar yang memberikan berbagai ilmu ke agamaan baik secara teori maupun langsung dipraktekkan, dengan cara pentransferan mengenai ilmu ke islaman. Dalam proses pentransferan itulah terdapat nilai-nilai yang ditanamkan. Proses penanaman nilai-nilai yang dilakukan oleh si ustaz (agen sosialisasi) dilakukan dalam tausiyah-tausiyah yang diberikan kepada ibu-ibu pengajian.

Materi yang diberikan oleh para ustaz- ustazah bisa memberikan kesadaran kepada para anggota pengajian khususnya para ibu-ibu yang termasuk dalam suatu kelompok pengajian tersebut. Dari pengajian itulah secara tidak langsng membentuk karakter anggotanya. Karakter yang dibentuk melalui latihan-latihan dan perhatian yang cukup. Proses pembentukan karakter diawali dari diri sendiri yang ingin berubah, para ibu-ibu dapat mengaplikasikan nilai-nilai ke islaman dari ustaz-ustazah baik untuk dirinya sendiri maupun untuk orang lain.

Materi tentang sedekah sangat menyentuh subjek EL, karena sedekah mempunyai keajaiban, hal tersebut seperti yang diungkapkan dalam buku Keajaiban Sedekah yang dikarang oleh Muhammad Muhyidin : "Sesungguhnya, pada skala yang normal, ketika kita memberi sesuatu di mana sesuatu itu memang dibutuhkan oleh orang yang membutuhkannya, maka ada dorongan 
E-ISSN : 2580-7056, ISSN : 2580-7064

Pascasarjana IAIN Palangka Raya

internal pada orang tersebut untuk membalas budi atas pemberian kita, minimal dia akan mengucapkan terima kasih". ${ }^{30}$

Apabila seseorang telah menyedekahkan sebahagian hartanya dan suka berbagi kepada orang lain dengan niat, cara, tujuan dan objek sedekah yang benar dan keutamaan-keutamaan, keajaiban-keajaiban serta ganjaran yang Allah berikan kepada orang yang bersedekah tersebut.

Implikasi subjek setelah mengikuti pengajian seperti subjek IH, sering melaksanakan sholat sunat tahajut dan di iringi dengan sholat dhuha, karna sholat tahajut adalah sholat yang sangat istemewa. Satu-satunya sholat sunah yang perintahnya langsung disebutkan dalam Al Qur'an serta disertai dengan keutamaannya.

Doa setelah sholat tahajut insyah di kabulkan Allah, terlebih lagi dikerjakan di sepertiga malam yag terakhir merupakan waktu yang paling istijabah untuk berdo'a, jadi apapun perrmintaan seseorang, selalu berdo'a kepada Allah baik untuk kebutuhan dunia maupun kebutuhan untuk akhirat.

Sholat Tahajut memiliki manfaat yang sangat besar jika dikerjakan secara rutin setiap malam. Karena manfaat ini pula, mengapa sehingga sholat tahajud sangat dianjurkan bagi umat muslim. Banyak dalil-dalil, baik itu AlQur'an maupun hadis yang memberikan penjelasan tentang kandungan manfaat yang dimiliki oleh sholat sepertiga malam ini. Beberapa diantaranya seperti, penghapus dosa, pembuka rejeki, pengabul doa, dan masih banyak lagi. Tentunya, semua itu hanya dapat diraih jika kita rajin untuk bertahajud. Mungkin, ini pula yang menjadi sebab, Rasulullah di sepanjang hidupnya tidak pernah meninggalkan sholat tahajut.

Selain sholat tahajut subjek IH juga mengamalkan sholat dhuha, karena menurut HI sholat Dhuha merupakan salah satu keutamaan atau manfaat sholat sunnah dhuha yaitu dilancarkannya pintu rezeki bagi orang yang menunaikannya. Shalat dhuha memang hukumnya tidak wajib, namun banyak sekali manfaatnya selain sebagai membuka pintu rezeki, Allah akan menjamin akan mencukupkan kebutuhan/ rezeki hambanya yang tidak bermalas-malasan dan senantiasa menjalankan shalat dhuha. ${ }^{31}$ Selain itu, ternyata ada beberapa Keutamaan Sholat Dhuha yang Sangat Luar Biasa, seperti; orang yang menunaikan sholat dhuha pahalanya menyamai pahala orang haji dan umrah yang sempurna, akan dimudahkan dan dicukupi segala urusannya hingga akhir siang, dan masih banyak lagi.

Implikasi yang di dapat oleh subjek setelah mengikuti pengajian dengan mendengar ceramah dari ustaz-ustazah, seperti yang di alami oleh subjek HA tentang kesabaran dalam menghadapi keluarga, tidak dapat dipungkiri alam sebuah rumah tangga sellu dihadapkan dengan berbagai problema, yang

\footnotetext{
${ }^{30}$ Muhammad Muhyidin, Keajaiban Shodekah, (Yogyakarta: PT Diva Press, 2007), h. 25

${ }^{31}$ Alice Syahputra, Testemoni Pengamal Sholat Dhuha, (Jakarta: Semesta Hikmah, 2011), h. 13
} 
E-ISSN : 2580-7056, ISSN : 2580-7064

Pascasarjana IAIN Palangka Raya

berkaitan erat dengan kelemahan/kekurangan dari masing-masing sebagai pasangan. Hal ini merupakan sebagai bagian dari sunnatullah, setiap orang mempunyai kelemahan, di samping juga bahwa setiap orang punya kelebihan/keutamaan/keistimewaan yang tidak dimiliki oleh orang lain. Menurut Imam Ghazali mengatakan ; bahwa hidup ini adalah antara sabar dan syukur, iman itu separuhnya adalah syukur, dan separuhnya lagi adalah sabar, maka demikian juga dengan kehidupan suami istri dalam keluarga. ${ }^{32}$ Kadang, pada saat tertentu, seorang suami yang harus bersabar, dengan kelakuan istri yang kurang berkenan di hatinya, dan pada saat itu istri bersyukur karena memiliki suami yang sabar. Di lain kesempatan, giliran istri yang harus bersabar, melihat kekurangan/kelemahan suami, sementara suami perlu bersyukur karena istrinya bisa bersabar.

Dalam Al Qur'an surah An Nisa ayat 19, Allah berfirman :

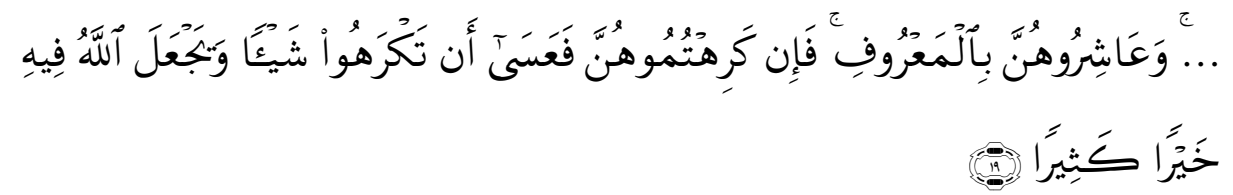

.... Dan bergaullah dengan mereka secara patut. Kemudian bila kamu tidak menyukai mereka, (maka bersabarlah) karena mungkin kamu tidak menyukai sesuatu, padahal Allah menjadikan padanya kebaikan yang banyak" (QS. An-Nisa 19).

Allah menjanjikan mengganti pahala yang besar bagi siapa saja dari hamba-Nya yang mampu bersabar. Oleh karenanya tidak ada cara lain selain kita harus terus meningkatkan kualitas diri dan belajar menjadi orang yang sabar.

Setelah mengikuti pengajian dan mendengarkan ceramah dari ustazustazah, perasaan rasa aman, tenang dan tentaram, hal ini seperti subjek SS. Menurut teori Maslow, tentang Kebutuhan-kebutuhan akan rasa aman ini diantaranya adalah rasa aman fisik, stabilitas, ketergantungan, perlindungan dan kebebasan dari daya-daya mengancam seperti kriminalitas, perang, terorisme, penyakit, takut, cemas, bahaya, kerusuhan dan bencana alam. ${ }^{33}$

Jika kebutuhan fisiologis dan kebutuhan akan rasa aman telah terpenuhi, maka muncullah kebutuhan akan cinta, kasih sayang dan rasa memiliki dan dimiliki. Kebutuhan-kebutuhan ini meliputi dorongan untuk dibutuhkan oleh orang lain agar ia dianggap sebagai warga komunitas sosialnya. Bentuk akan pemenuhan kebutuhan ini seperti bersahabat, keinginan memiliki pasangan dan

\footnotetext{
${ }^{32}$ Imam Al Ghazali, Terjemahan Kitab Ihya Ulumuddin Jilid 2, (Jakarta: Penerbit Asy Syifa,
} 1990), h. 115

${ }^{33}$ Feist, Jess; Gregory, Teori Kepribadian, (Jakarta : Salimba Humika, 2010), h. 331 
E-ISSN : 2580-7056, ISSN : 2580-7064

Pascasarjana IAIN Palangka Raya

keturunan, kebutuhan untuk dekat pada keluarga dan kebutuhan antarpribadi seperti kebutuhan untuk memberi dan menerima cinta.

Seseorang yang kebutuhan cintanya sudah relatif terpenuhi sejak kanakkanak tidak akan merasa panik saat menolak cinta. Ia akan memiliki keyakinan besar bahwa dirinya akan diterima orang-orang yang memang penting bagi dirinya. Ketika ada orang lain menolak dirinya, ia tidak akan merasa hancur Bagi Maslow, cinta menyangkut suatu hubungan sehat dan penuh kasih mesra antara dua orang, termasuk sikap saling percaya. Sering kali cinta menjadi rusak jika salah satu pihak merasa takut jika kelemahan-kelemahan serta kesalahankesalahannya. Maslow juga mengatakan bahwa kebutuhan akan cinta meliputi cinta yang memberi dan cinta yang menerima. Kita harus memahami cinta, harus mampu mengajarkannya, menciptakannya dan meramalkannya. Jika tidak, dunia akan hanyut ke dalam gelombang permusuhan dan kebencian.

Banyak implikasi yang di dapat oleh para ibu-ibu setelah mengikuti pengajian yang diajarkan oleh para ustaz -ustazah dalam memberikan berbagai macam materi pembelajaran agama yang disampaikan dengan tidak melu] tata cara metode pembelajaran agar mudah diterima oleh para ibu-ibu.

\section{PENUTUP}

\section{a. Kesimpulan}

Dari uraian dan gambaran yang penulis paparkan dapatlah ditarik kesimpulan sebagai berikut :

1. Motivasi ibu-ibu mengikuti Pengajian di BKMT Kota Palangka Raya sangat antusias, hal itu bisa dilihat dari banyaknya pengajian yang diikuti ibu-ibu baik pengajian rutin dalam seminggu atau pengajian yang dilaksanakan dalam sebulan. Ibu-ibu termotivasi mengikuti pengajian di karenakan ;
a. Menuntut ilmu agama dan memperdalam ilmu agama
b. Menganggap ikut pengajian adalah merupakan ibadah
c. Membuat batin atau jiwa menjadi tenang
d. Menjalin silaturrahmi di antara sesama anggota pengajian
e. Adanya uang arisan sebagai pengikat anggota

Adapun faktor-faktor yang memotivasi ibu-ibu ikut pengajian terbagi 2 (dua) macam, yakni :

a. Intern yang terdiri dari : minat atau keinginan sendiri, latar belakang pendidikan subjek yang cukup baik, dan juga pekerjaan dari subjek, yang dapat memotivasi ibu-ibu dalam mengikutin pengajian di BKMT Kota palangka Raya

b. Ekstren yang terdiri dari : ajakan dari orang lain atau teman sejawat, materi yang disampaikan oleh penceramah seperti fiqih/fiqih wanita, aqidah, akhlak, pendidikan anak, keutamaan sholawat, dan keluarga sakinah. Adapun metode yang digunakan oleh para penceramah dengan metode yang bervariasi (metode ceramah, tanyajawab dan demonstrasi), misalnya digunakannya metode demontrasi saat menjelaskan tentang thaharah 
E-ISSN : 2580-7056, ISSN : 2580-7064

Pascasarjana IAIN Palangka Raya

(Wudhu, Tayamum), materi sholat (sholat jama' dan sholat sunat). Sedangkan untuk membeikan ceramah/penceramah sebagian besar subjek menghendaki yang perempuan/ustazah, dengan alasan supaya leluasa, apalagi dengan masalah kewanitaan.

Adapun masalah tempat, sebagian subjek menghendaki di masjid dan ada juga yang menghendaki di rumah atau sesuai dengan kesepakatan. Kemudian mengenai waktu yang tepat untuk dilaksakannya penyajian ratarata subjek menghendaki di siang hari dan di sore hari.

2. Impikasi yang di dapat oleh para ibu-ibu setelah mengikuti pengajian cukup banyak, diantaranya :

a. Rajin bersilaturrahim

b. Suka Bersedekah

c. Lebih Sabar menghadapi persoalan dalam keluarga

d. Mengamalkan sholat Tahajut dan sholat Dhuha

e. Rajin membaca Al Qur'an

f. Rajin mengamalkan zikir-zikir

g. Pemaaf kepada teman-teman dan keluarga

h. Memiliki perasaan tenang dan tentram

\section{A. Saran-saran}

1. Bagi peneliti lainnya, agar dapat mengupas lebih tajam, mendalam dan lebih spesifik lagi berkaitan dengan motivasi

2. Bagi para ibu-ibu, agar bisa membagi waktu antara kegiatan pengajian dengan kewajiban di rumah tangga

3. Bagi ibu-ibu yang ikut pengajian, aga dapat mengimplikasikan segala ilmu yang di dapat, baik untuk diri sendiri, maupun berdampak juga dengan orang lain

4. Bagi para ustaz/ustazah agar memberikan materi mengenai, tentang kehidupan sehari-hari yang dilakukan oleh seseorang, dan juga menggunakan metode yang menarik, supaya tidak membosankan. 
E-ISSN : 2580-7056, ISSN : 2580-7064

Pascasarjana IAIN Palangka Raya

\section{DAFTAR PUSTAKA}

Abdul Halim Mahmud, Ali. 2000. Pendidikan Ruhani, Terjm. Abdul Hayyie al Kattani , Jakarta: Gema Insani Press.

Abror, Abd. Rachman, 1999., Psikologi Pendidikan. Yogyakarta : Tiara Wacana

Al Ghazali, Imam, 1990, Terjemahan Kitab Ihya Ulumuddin Jilid 2, Jakarta: Penerbit Asy Syifa

Barsihannor, Belajar dari Luqman al-Hakim, 2011.Yogyakarta : Kota Kembang

Daryanto, 1998. Kamus Besar Bahasa Indonesia, Surabaya: Apollo.

Departemen Agama, 2002. Al Qur'an dan Terjemahnya . Jakarta,

Desmita, 2011. Psikologi Perkembangan Peserta Didik, Bandung: PT Remaja Rosdakarya.

Dimyati, 2006. Belajar dan Pembelajaran, Jakarta: PT Asdi Mahastya.

Dipdikbud, 1989. Kamus Besar Bahasa Indonesia . Jakarta ; Balai Pustaka.

Effendy, 2004. Dasar-dasar Keperawatan Kesehatan Masyarakat.Jakarta, Rineka Cipta.

Feist, Jess; Gregory, 2010. Teori Kepribadian, Jakarta : Salimba Humika

H. M. Hafi Anshori, 1999. Pengantar Ilmu Pendidiakan, Surabaya: Usaha Nasional.

HM. Arifin, 1997. Psikologi dan Beberapa Aspek Kehidupan Rohani Manusia . Yogyakarta, Bulan Bintang.

M. Quraish Shihab, 1992. Membumikan Al-Quran: Fungsi dan Peran Wahyu dalam Kehidupan Masyarakat (Bandung: Mizan)

Margaret E. Bell-Gredler, 1994. Learning and Instuction (Belajar dan Pembelajaran), Terj. Munandir, Jakarta: PT RajaGrafindo Persada.

Muhsin, MK, 2009. Manajemen Majelis Taklim : Petunjuk Praktis Pengelolaan Dan Pembentukannya, Jakarta : Inter Massa. Cet. Ke 1

Muhyidin, Muhammad, 2007, Keajaiban Shodekah, Yogyakarta: PT Diva Press 
E-ISSN : 2580-7056, ISSN : 2580-7064

Pascasarjana IAIN Palangka Raya

Ngalim Purwanto, 2007. Psikologi Pendidikan, Bandung: PT Remaja Rosdakarya.

Niko Syukur Dister, 1994. Pengalaman dan Motivasi Beragama . Yogyakarta : Kanisius.

Noeng Muhadjir, 2010. Metodologi Kualitatif, Yogyakarta, Pustaka Pelajar

Oemar Hamalik, 2006. Proses Belajar dan Mengajar, Jakarta: PT Bumi Aksara

P. Siagian, Sondang, 1989. Teori Motivasi dan Aplikasinya, Jakarta: PT Rineka Cipta.

Purwanto,Ngalim, 2007. Psikologi Pendidikan, Bandung: PT Remaja Rosdakarya.

Santosa, Slamet, 2006. Dinamika Kelompok, Jakarta : Bumi Aksara

Syahputra, Alice, 2011, Testemoni Pengamal Sholat Dhuha, Jakarta: Semesta Hikmah,

Sardiman, 2000. Interaksi dan Motivasi Belajar-Mengajar, (Jakarta: PT RajaGrafindo Persada) Sabri, M.Alisuf, 1998. Psikologi Umum, (Jakarta ; Pedoman Ilmu Jaya)

Shaleh, Abdul Rahman, 2008. Psikologi: Suatu Pengantar Dalam Perspektif Islam, Jakarta: Kencana.

Siregar, Evelin. 2010. Teori Belajar dan Pembelajaran, Bogor: Ghalia Indonesia

Slameto, 2010. Belajar dan Faktor-faktor yang Mempengaruhinya, Jakarta: Rineka Cipta.

Tjahjono, Herry, 2007. The XO Way, Jakarta: PT Grasindo

UU RI Nomor 20 Tahun 2003, Bab IV pasal 27 ayat 1 . Bandung : Citra Umbara.

Yamin, Martinis, 2007. Profesionalisme Guru dan Implementasi KTSP. Jakarta: Gaung Persada Press Jakarta. 